\title{
Akt Isoforms: A Family Affair in Breast Cancer
}

\author{
Alakananda Basu *(D) and Christoffer Briggs Lambring \\ Department of Microbiology, Immunology and Genetics, University of North Texas Health Science Center, \\ Fort Worth, TX 76107, USA; ChristofferLambring@my.unthsc.edu \\ * Correspondence: Alakananda.basu@unthsc.edu; Tel.: +1-817-735-2487
}

check for

updates

Citation: Basu, A.; Lambring, C.B. Akt Isoforms: A Family Affair in Breast Cancer. Cancers 2021, 13, 3445. https://doi.org/10.3390/

cancers 13143445

Academic Editor: Emilio Hirsch

Received: 17 June 2021

Accepted: 7 July 2021

Published: 9 July 2021

Publisher's Note: MDPI stays neutral with regard to jurisdictional claims in published maps and institutional affiliations.

Copyright: (C) 2021 by the authors Licensee MDPI, Basel, Switzerland. This article is an open access article distributed under the terms and conditions of the Creative Commons Attribution (CC BY) license (https:/ / creativecommons.org/licenses/by/ $4.0 /)$.
Simple Summary: Breast cancer is the second leading cause of cancer-related death in women in the United States. The Akt signaling pathway is deregulated in approximately $70 \%$ of patients with breast cancer. While targeting Akt is an effective therapeutic strategy for the treatment of breast cancer, there are several members in the Akt family that play distinct roles in breast cancer. However, the function of Akt isoforms depends on many factors. This review analyzes current progress on the isoform-specific functions of Akt isoforms in breast cancer.

Abstract: Akt, also known as protein kinase B (PKB), belongs to the AGC family of protein kinases. It acts downstream of the phosphatidylinositol 3-kinase (PI3K) and regulates diverse cellular processes, including cell proliferation, cell survival, metabolism, tumor growth and metastasis. The PI3K/Akt signaling pathway is frequently deregulated in breast cancer and plays an important role in the development and progression of breast cancer. There are three closely related members in the Akt family, namely $\mathrm{Akt} 1(\mathrm{PKB} \alpha), \mathrm{Akt} 2(\mathrm{PKB} \beta)$ and $\mathrm{Akt} 3(\mathrm{PKB} \gamma)$. Although Akt isoforms share similar structures, they exhibit redundant, distinct as well as opposite functions. While the Akt signaling pathway is an important target for cancer therapy, an understanding of the isoform-specific function of Akt is critical to effectively target this pathway. However, our perception regarding how Akt isoforms contribute to the genesis and progression of breast cancer changes as we gain new knowledge. The purpose of this review article is to analyze current literatures on distinct functions of Akt isoforms in breast cancer.

Keywords: Akt isoforms; regulation; breast cancer initiation and progression; cell proliferation; autophagy; senescence; metabolism; tumorigenesis; metastasis; AGC kinase

\section{Introduction}

Breast cancer is the second leading cause of cancer-related death, affecting 1 in 8 women in the United States. It is also a common cancer worldwide. It is anticipated that approximately 281,550 cases will be diagnosed, and 43,600 women are expected to die from breast cancer in 2021 (breastcancer.org, 1 May 2021). Based on PAM50 gene expression profiling, breast cancer is categorized in four different subtypes: luminal A, luminal B, HER2-enriched and basal-like [1]. The status of estrogen receptor (ER), progesterone receptor (PR) and epidermal growth factor receptor 2 (HER2) detected by immunohistochemistry is used in the clinic to decide treatment strategy for breast cancer [2]. While luminal A breast cancers are ER-positive, PR-positive and HER2-negative, luminal B breast cancers are ER-positive, PR-negative and HER2-positive. HER2-enriched breast cancers are negative for ER and PR but overexpress HER2 whereas basal-like (BL) breast cancers do not express ER, PR or HER2 and are often used synonymously with triple-negative breast cancer (TNBC).

The phosphatidylinositol 3-kinase (PI3K)/Akt signaling pathway is frequently deregulated in breast cancer $[3,4]$. PI3K contains a p85 regulatory subunit and a p110 catalytic subunit. In response to growth factors, the lipid kinase activity of class I PI3K becomes activated and generates the second messenger PIP3 from PIP2, resulting in the activation of 
Akt [5]. The lipid phosphatase activity of the tumor suppressor PTEN, which dephosphorylates PIP3, causes inactivation of PI3K, thereby inhibiting Akt [6]. Although mutations in Akt are rare, activating mutations in the catalytic subunit of p110 PI3K (PIK3CA) have been found in breast cancer [7]. In addition, amplification of HER2 as well as mutations in PTEN could also result in the activation of PI3K/Akt signaling. Mutations in PIK3CA are most common in luminal type of breast cancer [8,9], but have also been found in TNBC $[3,10]$. HER2 is often amplified in HER2-enriched breast cancer whereas decreased PTEN and increased EGFR expression is associated with TNBC [9]. Reduction in PTEN levels were also associated with lymph node metastases and poor prognosis of breast cancer [11].

Akt belongs to the AGC group of serine/threonine protein kinases and is also known as protein kinase $B$ due to its similarities with protein kinase $A$ and protein kinase $C$ [12-14]. It regulates many cellular processes including cell proliferation, cell survival, metabolism and metastasis $[15,16]$. It is a major mediator of the oncogenic signaling acting downstream of PI3K. There are three members in the Akt family, namely, Akt1(PKB $\alpha), A k t 2(\mathrm{PKB} \beta)$ and Akt3(PKB $\gamma$ ) [17]. Although the overall structure of Akt isoforms is similar, they exhibit redundant and even opposite functions depending on the cellular context. In this review article, we have discussed recent advancements on the understanding of distinct functions of Akt isoforms in breast cancer.

\section{Structural Heterogeneity and Regulation of Akt Isoforms}

Three members of the Akt family Akt1, Akt2 and Akt 3 are encoded by distinct genes located in chromosomes 14q32 [18], 19q13 [19] and 1q44 [20], respectively. All three Akt isoforms contain an $\mathrm{N}$-terminal pleckstrin homology $(\mathrm{PH})$ domain, a central kinase domain and a C-terminal regulatory domain that contains a hydrophobic motif (HM) site. While the linker region that tethers the $\mathrm{PH}$ to the catalytic domain is divergent, there is considerable sequence homology among these domains [21,22].

Activity of Akt is regulated by conformational changes and phosphorylation. Akt isoforms can be phosphorylated at approximately 20 different sites and differential phosphorylation of Akt isoforms may be responsible for distinct substrate specificities and their non-redundant functions [23]. Akt is phosphorylated at the conserved activation loop (A-loop or AL), turn motif (TM) and hydrophobic motif (HM) sites. In the absence of a stimulus, the interaction of the PH domain with the kinase domain maintains Akt in an inactive compact structure in the cytosol [24]. When PI3K becomes activated, it phosphorylates phosphoinositides to generate the second messenger phosphatidylinositol $(3,4,5)$-trisphosphate (PIP3) from phosphatidylinositol (4,5)-bisphosphate (PIP2) (Figure 1). According to the canonical model, PIP3 binds to the PH domain of Akt inducing its membrane recruitment and conformational change which relieves its negative regulation. Phosphoinositide-dependent kinase 1 (PDK1) also contains a PH domain. Thus, the generation of PIP3 facilitates recruitment of PDK1 to the membrane where it phosphorylates Akt at the activation loop (T308, T309, T305 in Akt1, Akt2, and Akt3, respectively) [25]. Mechanistic target of rapamycin complex 2 (mTORC2) phosphorylates Akt at the C-terminal $\mathrm{HM}$ site (S473, S474, S472 in Akt1, Akt2, and Akt3, respectively) resulting in full activation of Akt $[17,26]$. It is believed that in response to insulin or growth factors, mTORC2 phosphorylates Akt at the HM site whereas during DNA damage or stress, DNA-PK is primarily responsible for HM phosphorylation [27]. Several other kinases including mitogen-activated protein kinase (MAPK) [28], integrin-linked kinase (ILK) [29], protein kinase C (PKC)- $\alpha$ [30], PKC $\beta$ II [31], ataxia telangiectasia mutated (ATM) [32], IКB kinase- $\mathrm{K}$ $(\mathrm{IKK} \varepsilon$ )/TANK-binding kinase 1 (TBK1) [33] IKB kinase- $\alpha$ (IKK $\alpha$ ) [34] and cyclin D1 [35] have been implicated in phosphorylating Akt at the HM site. It was suggested that HM site phosphorylation is regulated by autophosphorylation and is independent of mTORC2 but depends on the removal of the PH domain from the kinase domain and phosphorylation at the A-loop by PDK1 [36]. Once activated, Akt translocates to different compartments to transduce signals [37]. 


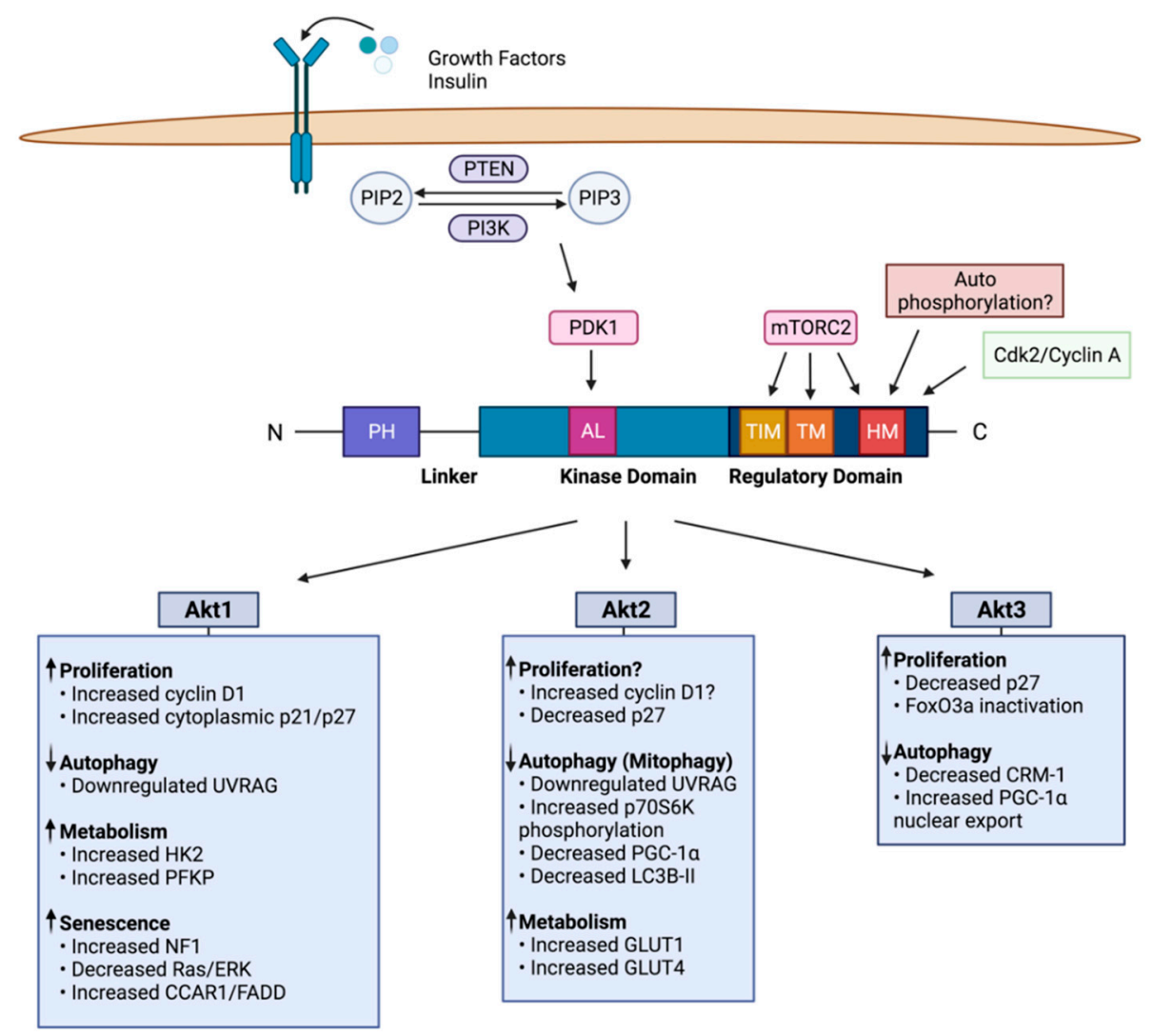

Figure 1. Regulation of cellular processes by Akt isoforms. Phosphorylation of Akt isoforms by upstream kinases triggers distinct cellular responses as indicated by upward and downward arrows. AL-activation loop, TIM-TOR interacting motif, TM-turn motif, HM-hydrophobic motif, $\mathrm{PH}$ pleckstrin homology.

Akt is phosphorylated at the turn motif (TM) independent of growth factor stimulation of PI3K activity. The TM site is phosphorylated co-translationally by mTORC2 (T450, T451 and T447 in Akt1, Akt2, and Akt3, respectively) and is required for Akt folding, maturation, and stability but does not directly regulate Akt activity [38]. Although mTORC2 mediates phosphorylation of both HM and TM sites of Akt, phosphorylation at these sites have differential effects on Akt activity. HM phosphorylation enhances phosphorylation at the A-loop and increases Akt activity whereas TM phosphorylation induces dephosphorylation of A-loop phosphorylation, thus decreasing Akt activity [39]. A recent study identified additional mTORC2-regulated phosphorylation sites termed TOR interacting motif (TIM) at the C-terminal tail [40]. These sites are conserved among AGC kinases (Akt1-T443, Akt-T444, Akt3-T440) and regulate A-loop phosphorylation by PDK1. Although there are controversies whether mTORC2 directly phosphorylates HM site or not, it can regulate Akt activity by phosphorylating TIM [40].

The C-terminal regulatory tail contains additional phosphorylation sites S477 and S479 (Akt1) which can be phosphorylated in a manner dependent on cell cycle progression [41]. Phosphorylation of these sites by cyclin-dependent kinase 2 (Cdk2/cyclinA) results in Akt activation [41]. S477/S479 sites were also phosphorylated by mTORC2 or DNA-PK in response to insulin or DNA damage, respectively. A correlation between S477/S479 phosphorylation and cyclin A2 expression was found in breast cancer patient samples [41]. Cdk2/cyclin A also phosphorylated Akt2 at S478 and synergized with S474 phosphorylation at the HM site to allosterically activate Akt2 [41]. Recently, it was reported that amino acids 44-46 (DVD) at the PH domain affect C-terminal phosphorylation [42]. Triple mutation of DVD (Asp Val Asp) to GPG (Gly Pro Gly) affected phosphorylation of Akt at S473 and T308 but not at S477 and S479. All three Akt isoforms undergo alternate 
splicing to generate splice variants with altered C-termini that lack the regulatory HM phosphorylation sites and additional C-terminal phosphorylation sites (Ser477 and Tyr479 for Akt1) [43].

Dephosphorylation of Akt results in inactivation of Akt and termination of Akt signaling. Dephosphorylation of $\mathrm{PI}(3,4,5) \mathrm{P}_{3}$ and $\mathrm{PI}(3,4) \mathrm{P}_{2}$ to $\mathrm{PI}(4,5) \mathrm{P} 2$ and $\mathrm{PI}(3) \mathrm{P}$ by PTEN [44] and INPP4B (inositol polyphosphate 4-phosphatase type II) [45], respectively results in inactivation of PI3K/Akt. Protein phosphatase 2A (PP2A) and the PH domain and leucine-rich repeat protein phosphatases (PHLPP) can directly dephosphorylate Akt. PP2A dephosphorylates the A-loop (T308 for Akt1) site [46] whereas PHLPP dephosphorylates the HM site [47]. There are two isoforms PHLPP1 and PHLPP2 with distinct specificities towards Akt isoforms [48]. While PHLPP2 dephosphorylates Akt1 and Akt3, PHLPP1 dephosphorylates Akt2 and Akt3.

The activity of Akt is also regulated by additional post-translational modifications, such as methylation and ubiquitination [49,50]. TRAF6 (tumor necrosis factor receptorassociated factor 6)-mediated ubiquitination of Akt was required for its membrane localization, phosphorylation and activation [51]. Both Akt1 and Akt2 were shown to interact with TRAF6 ubiquitin ligase. Methylation of Akt1 at K64 by the histone-lysine $\mathrm{N}$-methyltransferase SETDB1 was essential for the recruitment of TRAF6 and Skp2-SCF ubiquitin ligase to Akt to trigger ubiquitination, membrane recruitment and phosphorylation/activation of Akt [49]. AKT E17K mutant exhibited enhanced methylation and ubiquitination [49,50]. Methylation of Akt2 and Akt3 was much less compared to Akt1 [49]. The mitochondrial E3 ubiquitin protein ligase 1 (Mul1 or MULAN) was shown to interact with active phosphorylated Akt1 and Akt2 to trigger their degradation, thus negatively regulating Akt signaling [52].

\section{Genetic Alterations of Akt Isoforms}

No mutations in the catalytic domain of Akt isoforms were detected in breast cancer specimens. A somatic mutation of Glu17 to Lys (E17K) in the PH domain of $A k t 1$ gene was shown to change conformation causing plasma membrane localization and constitutive activation of Akt1 [53] but it was only weakly constitutively active [54]. The overall prevalence of Akt1 E17K mutation was $6.3 \%$ in breast cancers but it varied with tumor grade (11.1\% in grade 1 and $1.9 \%$ in grade 3$)$. While $A k t 1$ E17K may serve as an oncogene in some luminal breast cancers [55], additional mutations may be required to promote tumorigenesis [17]. Recently, an OncoOmics approach that consisted of genomic alterations, signaling pathways, protein-protein interaction network and protein expression in cell lines and patient-derived xenografts was used to determine breast cancer dependency and $A k t 1$ was shown to be an essential gene in at least three different OncoOmics approaches [56]. Akt1 E17K mutation was restricted to hormone receptor-positive luminal breast cancers [57-59]. Similar mutation in Akt2 and Akt3 was rare $[3,60]$. Based on next-generation sequencing analysis, genetic alteration in $A k t 1$ (E17K and other pathologic mutations) was significantly enriched in metastatic breast cancer compared to primary breast cancer and Akt1, but not Akt2 or Akt3, was identified as an actionable target [61].

It has been reported Akt2 was amplified in 3\% of breast cancers [62] and Akt3 is frequently amplified in TNBC [63]. Based on TCGA dataset, Akt3 is most amplified followed by Akt2 and amplification of Akt1 was least among Akt isoforms in breast cancer [64]. A recurrent MAGI3-AKT3 fusion that resulted in constitutive activation of Akt was enriched in TNBC [65]. Akt1 copy gain/high mRNA expression was associated with poor prognosis of basal-like 2 (BL2) breast cancer, a subgroup of TNBC [66].

\section{Function of Akt Isoforms}

Akt was originally discovered as an oncogene. While oncogenes contribute to tumorigenesis by increasing cell proliferation, they must overcome several barriers, including apoptosis and senescence and gain the ability to invade and metastasize to acquire a fully malignant phenotype. There have been numerous studies on the anti-apoptotic function of 
Akt. Most of the earlier studies have been focused on Akt1. Knockout of individual Akt isoform in mice revealed their distinct functions [67]. In the following section, we have discussed how Akt isoforms regulate various cellular processes that contribute to breast cancer pathogenesis (Figure 1 and Table 1).

\subsection{Cell Proliferation and Survival}

Cell cycle progression depends on the activity of cyclin dependent kinases (CDK) which require cyclins for their activation. Induction of cyclin D activates CDK4/6 which phosphorylates and inactivates tumor suppressor protein $\mathrm{Rb}$ to allow cell cycle progression [68]. Cyclin-dependent kinase inhibitors (CKI), such as p21 and p27 encoded by $C D K N 1 A$ and $C D K N 1 B$, respectively, inhibit CDK2-cyclin E and CDK2-cyclin A complexes halting cell cycle progression [69].

Akt1, but not Akt2, was shown to promote breast cancer cell proliferation by upregulating cyclin D1 and S6 (a downstream target of mTORC1) in IBH-6 and T47D breast cancer cells [70]. A recent study showed that there is cross-regulation between Akt1 and cyclin D1 [35]. Extranuclear membrane-associated cyclin D1 was shown to associate with Akt1 and enhanced Akt1 activity both in vitro and in vivo in response to growth factors and increased cell proliferation [35]. Akt1 gene expression signature positively correlated with cyclin D1 gene expression signature in different subtypes of breast cancer with highest significance in luminal A, luminal B and basal type [35].

There are controversies regarding the role of Akt2 on cell proliferation. Santi et al. reported that $\mathrm{Akt} 2$, but not $\mathrm{Akt1}$ or $\mathrm{Akt} 3$, played a more prominent role in augmenting cell proliferation in triple-negative breast cancer MDA-MB-231 cells [71]. Silencing of Akt2 induced cell cycle arrest at the G0/G1 phase by downregulating cyclin D1. Another study, however, showed that knockdown of Akt1, but not Akt2, decreased cyclin D1 expression and inhibited MDA-MB-231 cell proliferation [72]. Recently, Akt2-specific nanobodies that bind to the hydrophobic motif of Akt2 and reduce phosphorylation of Akt2 at the $\mathrm{HM}$ site were developed [73]. These Akt2 nanobodies inhibited cell cycle progression of MDA-MB-231 cells at the G0/G1 phase by decreasing cyclin D1 levels [73].

The mechanisms by which CKIs, such as p21 or p27 regulate cell cycle progression are complex. p21 and p27 inhibit cell cycle progression when localized in the nucleus. Phosphorylation of p21 at Ser145 and p27 at Thr157/Thr198 alters their localization from the nucleus to the cytosol where they cannot inhibit cell cycle progression [74-78]. HeronMilhavet et al. showed that Akt1 phosphorylates p21 at T145 and induces its cytoplasmic localization in myoblasts whereas Akt2 interacts with unphosphorylated p21 at the nucleus causing an increase in p21 and cell cycle exit [79]. Phosphorylation of p21 by Akt1 prevented interaction of p21 with Akt2 and localized p21 to the cytosol [79]. Phosphorylation of p21 at S146 by Akt increased its stability in MCF-7 cells and promoted cell survival [78]. Although p21 is believed to inhibit cell proliferation, it could also enhance cell cycle progression at the G1/S phase by promoting the assembly and activation of cyclin DCDK4/6 [78]. S146-p21 did not interact with or inhibit cyclin E-CDK2, but increased cyclin D1 level [78]. Akt1-mediated phosphorylation, cytoplasmic translocation, and stabilization of Skp2 caused degradation of p27 [80] and accumulation of cytoplasmic T157-p27 correlated with Akt activity in primary breast cancer tissues [75,81]. Thus, Akt1 can increase cell proliferation not only by altering the levels of p21 and p27, but also by inducing their nucleo-cytoplasmic shuttling. 
Table 1. Function of Akt isoforms.

\begin{tabular}{|c|c|c|c|c|c|}
\hline $\begin{array}{l}\text { Akt } \\
\text { Isoform }\end{array}$ & Cell line/Model System & Expression & Phenotype/Function & Potential Mechanisms & Ref \\
\hline Akt2 & MDA-MB-231 & Akt2 siRNA & $\downarrow$ Cell proliferation, $\uparrow$ Mitophagy & $\downarrow$ Cyclin D1, $\uparrow$ p27, $\downarrow$ mTORC $1, \uparrow$ PGC- $1 \alpha$ & [71] \\
\hline Akt1 & MDA-MB-231 & Akt1 siRNA & $\downarrow$ Cell proliferation, $\uparrow$ Apoptosis & $\downarrow$ Cyclin D1 & [72] \\
\hline Akt1 & SKBR3 & Akt1 siRNA & $\downarrow$ Cell proliferation & $\uparrow \mathrm{p} 27$ & [80] \\
\hline Akt1 & \multirow[t]{3}{*}{ MDA-MB-231 cell line \& xenograft } & Akt1 siRNA & $\downarrow$ Cell proliferation \& tumor growth & & \multirow[t]{3}{*}{ [82] } \\
\hline Akt2 & & Akt2 siRNA & No effect on cell proliferation \& tumor growth & & \\
\hline Akt3 & & Akt3 siRNA & $\downarrow$ Cell proliferation \& tumor growth & & \\
\hline Akt3 & Mouse mammary tumor $\mathrm{C} 4$ cells & Akt3 shRNA & $\downarrow$ Cell proliferation, $\uparrow$ Tamoxifen sensitivity & $\downarrow$ pErbB2 $/$ pErbB3,$\downarrow$ Foxo3a, $\uparrow$ ER $\alpha$ & [83] \\
\hline Akt3 & MDA-MB-468 \& MCF10DCIS xenografts & Akt3 shRNA & $\downarrow$ TNBC growth in 3D culture \& xenografts & $\uparrow \mathrm{p} 27$ & [63] \\
\hline Akt3 & 3475 (metastatic MDA-MB-231 cell line) & Overexpression of Akt3/-S472 & $\downarrow$ Tumor growth \& metastasis, $\uparrow$ Apoptosis & $\downarrow \mathrm{ERK}, \uparrow \operatorname{Bim}, \uparrow$ Bax activation & [84] \\
\hline Akt1 & \multirow[t]{2}{*}{ MDA-MB-231 } & CA-Akt1 (Myr-Akt1) & $\downarrow$ Autophagy & $\downarrow$ UVRAG & \multirow[t]{2}{*}{ [85] } \\
\hline Akt2 & & CA-Akt2 (Myr-Akt2) & $\downarrow$ Autophagy & $\downarrow$ UVRAG & \\
\hline Akt2 & * MDA-MB-435 & WT Akt2 cDNA & $\uparrow$ Invasion \& metastasis & $\uparrow \beta 1$-integrin & [86] \\
\hline Akt1 & Transgenic mice with activated ErbB-2 & Activated Akt1 (Akt1-DD) & $\uparrow$ Cell proliferation, $\uparrow$ Tumorigenesis, $\downarrow$ Metastasis & $\uparrow$ Cyclin D1, $\uparrow \mathrm{Rb}$ phosphorylation & [87] \\
\hline Akt1 & Transgenic mice expressing & Activated Akt1 (Akt1-DD) & $\uparrow$ Tumorigenesis, $\downarrow$ Metastasis & $\uparrow$ Nuclear ER $\alpha$ & [88] \\
\hline Akt1 & \multirow{2}{*}{$\begin{array}{l}\text { IGF-IR-overexpressing MCF-10A cell } \\
\text { monolayer and 3D culture }\end{array}$} & Akt1 siRNA & $\downarrow$ Cell proliferation, $\uparrow$ EMT, $\uparrow$ Migration & \multirow{2}{*}{$\uparrow$ ERK activity } & \multirow[t]{2}{*}{ [89] } \\
\hline Akt2 & & Akt2 siRNA & $\downarrow$ Cell proliferation, $\downarrow$ EMT, $\downarrow$ Migration & & \\
\hline Akt1 & MDA-MB-231 & CA-Akt1 (Myr-Akt1) & $\downarrow$ Migration & $\uparrow$ Palladin phosphorylation (S507) & [90] \\
\hline Akt1 & MDA-MB-231, * MDA-MB-435, SUM-159-PT & CA-Akt1 (Myr-Akt1) & $\downarrow$ Migration and invasion & $\uparrow$ HDM2 phosphorylation, $\downarrow$ NFAT1 & [91] \\
\hline Akt1 & T4-2 cells and mouse xenografts & CA-Akt1 & $\uparrow$ Tumor growth, $\downarrow$ Cell migration \& invasion & $\uparrow$ T1462 TSC2, $\downarrow$ TSC2, $\downarrow$ Rho-GTPase & [92] \\
\hline Akt2 & MCF-7 and * MDA-MB- 435 cells & Akt2 siRNA & $\downarrow$ Migration \& invasion & Transactivation of Akt2 by Twist & [93] \\
\hline Akt1 & IBH-6, T47D & shAkt1 & $\downarrow$ Tumor growth, $\uparrow$ Migration \& invasion & $\downarrow$ Cyclin D1, $\uparrow \beta 1$-integrin \& FAK & [70] \\
\hline Akt2 & & shAkt2 & $\downarrow$ Migration, invasion \& lung metastases & $\downarrow$ F-Actin \& vimentin & \\
\hline \multirow[t]{2}{*}{ Akt1 } & MCF-10A, MCF-7 and BT474 cells & Akt1 siRNA & $\uparrow \mathrm{EMT}$ & \multirow[t]{2}{*}{$\downarrow \mathrm{miR}-200, \uparrow$ Zeb1, $\downarrow$ E-cadherin } & \multirow[t]{2}{*}{ [94] } \\
\hline & MMTV-cErbB2 mice & Akt1 knockout & $\uparrow$ Migration \& invasion & & \\
\hline Akt1 & MCF-7, BT-474, MDA-MB-231, SKBR3 & Akt1 siRNA & $\uparrow \mathrm{EMT}$ and invasion & $\uparrow$ EGFR/ERK activity, $>\uparrow$ Nuclear $\beta$-catenin & [95] \\
\hline
\end{tabular}


Table 1. Cont.

\begin{tabular}{|c|c|c|c|c|c|}
\hline $\begin{array}{c}\text { Akt } \\
\text { Isoform }\end{array}$ & Cell line/Model System & Expression & Phenotype/Function & Potential Mechanisms & Ref \\
\hline Akt2 & $\begin{array}{l}\text { MDA-MB-231, MDA-MB-468, MCF-7, } \\
\text { SKBR-3 cells \& MDA-MB-231 xenografts }\end{array}$ & Akt2 siRNA & $\begin{array}{c}\downarrow \text { Non-CSC reversion, } \downarrow \text { CSC survival } \\
\downarrow \text { EMT and invasion }\end{array}$ & $\downarrow$ Twist, $\downarrow$ mTOR & [96] \\
\hline $\begin{array}{l}\text { Akt1 } \\
\text { Akt2 }\end{array}$ & MCF-10A, p53-null background, MCF-7 & $\begin{array}{l}\text { Akt1 E17K } \\
\text { Myr-Akt2 }\end{array}$ & $\uparrow$ Cell growth, $\downarrow$ Migration \& invasion & $\begin{array}{c}\downarrow \text { Zeb1, } \uparrow \text { E-cadherin } \\
\uparrow \beta \text {-catenin transcription, } \downarrow \text { E-cadherin }\end{array}$ & [97] \\
\hline Akt3 & MDA-MB-231 BO cells \& xenografts & Akt3 siRNA & $\uparrow$ Migration, invasion and bone metastasis & $\uparrow$ HER2 and DDR kinase, $\downarrow$ CTGF & [98] \\
\hline Akt1 & $\begin{array}{l}\text { Transgenic MMTV-ErbB2 mice } \\
\text { Monolayer \& 3D culture of MEC }\end{array}$ & Akt1 knockout & $\begin{array}{l}\downarrow \text { Cell proliferation, } \downarrow \text { Tumor growth } \\
\downarrow \text { Cell migration and Lung metastases }\end{array}$ & $\begin{array}{c}\downarrow \text { p21, p27 \& cyclin D1 } \\
\downarrow \text { TSC2 phosphorylation (S939), } \downarrow \text { CXCL-16 }\end{array}$ & [99] \\
\hline Akt1 & Immortalized MEC & Akt1 and vAkt1 & $\uparrow$ Invasion & $\downarrow$ MMP2 degradation & [101] \\
\hline $\begin{array}{l}\text { Akt1 } \\
\text { Akt2 } \\
\text { Akt3 }\end{array}$ & $\begin{array}{c}\text { IBC cells-SUM149 } \\
\text { nIBC cells-MDA-MB-231 \& * MDA-MB-435 }\end{array}$ & $\begin{array}{l}\text { Akt1 siRNA } \\
\text { Akt2 siRNA } \\
\text { Akt3 siRNA }\end{array}$ & $\begin{array}{c}\downarrow \text { IBC cell invasion, no effect in nIBC cells } \\
\downarrow \text { nIBC cell invasion, no effect in IBC cells } \\
\downarrow \text { Survival of IBC but not nIBC cells } \\
\text { No effect on invasion in IBC \& nIBC cells }\end{array}$ & $\downarrow$ RhoC GTPase activity & [102] \\
\hline $\begin{array}{l}\text { Akt1 } \\
\text { Akt2 } \\
\text { Akt1 } \\
\text { Akt2 } \\
\text { Akt1 } \\
\text { Akt2 } \\
\text { Akt1 } \\
\text { Akt2 }\end{array}$ & $\begin{array}{l}\text { HER2-enriched MMTV-NIC mouse model } \\
\text { HER2-enriched MMTV-ErbB2 mouse model } \\
\text { Luminal B MMTV-PyMT mouse model } \\
\text { Luminal B MMTV-PyMT mouse model }\end{array}$ & $\begin{array}{l}\text { Cell-autonomous Akt1 deletion } \\
\text { Cell-autonomous Akt2 deletion } \\
\text { Systemic Akt1 deletion } \\
\text { Systemic Akt2 deletion } \\
\text { Cell-autonomous Akt1 deletion } \\
\text { Cell-autonomous Akt2 deletion } \\
\text { Systemic Akt1 deletion } \\
\text { Systemic Akt2 deletion }\end{array}$ & $\begin{array}{c}\downarrow \text { Tumor development, No effect on lung metastasis } \\
\downarrow \text { Tumor development completely } \\
\downarrow \text { Tumor growth, } \downarrow \text { metastasis completely } \\
\uparrow \text { Tumor growth, } \uparrow \text { metastasis markedly } \\
\text { No effect on metastasis } \\
\text { No effect on metastasis } \\
\text { Improved tumor-free survival, } \downarrow \text { lung metastasis } \\
\text { No effect on survival or lung metastasis }\end{array}$ & $\begin{array}{l}\downarrow \text { Survival \& mobilization of neutrophil } \\
\uparrow \text { Akt1 activity }\end{array}$ & [103] \\
\hline
\end{tabular}

* Please note that although MDA-MB-435 cells were originally isolated as breast cancer cells, based on cell authentication they are now characterized as melanoma cells. 
Akt2 on the other hand was shown to interact with Prohibitin 2/Repressor of Estrogctivator (PHB2/REA) which has been implicated in transcriptional repression of myogenesis in estrogen-dependent cancers like breast cancer [104,105]. Using N-terminal truncation, Heron-Milhavet et al. showed that Akt2 directly binds p21 on a 27 amino acid sequence at 410-437 in the C-terminal domain of Akt2 leading to cell cycle arrest and myogenic differentiation [106]. Santi et al., however, reported that Akt2 increased cell proliferation in MDA-MB-231 cells by reducing p27 levels [71]. Akt2 had no effect on T157/T198 phosphorylation which has been associated with cytoplasmic localization, but Akt2 knockdown enhanced phosphorylation of p27 at Thr187 due to a decrease in Skp2 which targets T187p27 for degradation via the ubiquitin proteasome-mediated pathway [71]. In addition, miRNA-615 which directly targets Akt2, inhibited MDA-MB-231 cell proliferation by upregulating p21 and p27, implicating a role for Akt2 in cell proliferation [107]. In contrast, Toulany and colleagues showed that knockdown of Akt1 and to some extent Akt3, but not Akt2, inhibited cell proliferation and tumor growth in K-Ras-mutated MDA-MB-231 cells [82]. The reason for the contradictory results from different laboratories with the same cell line is not clear except Santi et al. [71] and Bai et al. [107] depleted Akt2 by siRNA or miRNA and monitored overall cell growth using MTT assay whereas Toulany et al. selected shRNA-transfected MDA-MB-231 cells and assessed clonogenic activity in vitro and tumor growth in vivo [82].

It has been reported that Akt3 can contribute to the proliferation of ErbB2 (HER2)positive breast cancers which express low levels of ER $\alpha$ and contribute to endocrine resistance [83]. Knockdown of Akt1 and Akt3 in ErbB2-positive Er $\alpha$-negative mouse mammary tumor $\mathrm{C} 4$ cells caused a substantial decrease in cell proliferation whereas Akt2 knockdown had only a modest effect [83]. Knockdown of Akt3 induced ER $\alpha$ via FoxO3a and restored sensitivity to tamoxifen. However, the most significant effects of Akt3 in terms of growth and proliferation of breast cancer have been shown in TNBC. Search for potential targets of TNBC using short hairpin RNA screen of protein kinases identified Akt3 as a regulator of TNBC cell growth [63]. Silencing of Akt3 with shRNA inhibited threedimensional (3D) spheroid growth and TNBC xenografts in nude mice via upregulation of p27 [63]. Akt3 is also a target of miRNA-433 which inhibits cell proliferation and cell survival of TNBC cells by downregulating Akt3 [108]. Analysis of clinical samples of breast cancer tissues revealed an inverse relationship between miRNA-433 and Akt3 mRNA, the latter being much higher in breast cancer patient samples compared to normal breast tissues [108]. A splice variant of Akt3 that lacks Ser472 phosphorylation site induced apoptosis and suppressed TNBC 3475 cell (a metastatic subline of MDA-MB-231 cells) growth in vivo by upregulating pro-apoptotic Bcl-2 family member BIM but had no effect on the proliferation of these cells [84].

\subsection{Autophagy}

Autophagy is a process of self-cannibalism that allows cells to survive under nutrientdeprived or stressful conditions [109]. Autophagy also plays an important role in breast cancer development and progression [110]. Although autophagy is considered a survival mechanism [111] it can also cause cell death and tumor suppression [112,113]. mTORC1, which functions downstream of Akt, is considered the master regulator of autophagy [109]. There are different types of autophagy depending on the organelles that are affected. For example, bulk degradation of cellular organelles is known as macroautophagy and often used synonymously with autophagy whereas selective degradation of specific organelles, such as mitochondria is known as mitophagy.

Santi et al. reported that knockdown of Akt2 in MDA-MB-231 cells attenuated phosphorylation of p70 S6 kinase (p70S6K) at Thr389 site, indicating inhibition of mTORC1 activity [71]. Akt2 was shown to physically associate with mitochondria and prolonged knockdown of Akt2, but not Akt1 or Akt3, induced mitochondrial biogenesis by upregulating peroxisome proliferator-activated receptor coactivator- $1 \alpha$ (PGC-1 $\alpha)$ and ultimately 
led to cell death by mitophagy. Thus, Akt2 promoted survival of MDA-MB-231 cells by protecting against mitophagy. However, knockout of individual Akt isoform in mice revealed that Akt3 but not Akt1 promotes mitochondrial biogenesis. Ablation of Akt3 induced autophagy by stabilizing nuclear export protein CRM- 1 which exports PGC- $1 \alpha$ from the nucleus to the cytoplasm causing a decrease in PGC- $1 \alpha$-dependent gene expression and mitochondrial content [114]. Yang et al. on the other hand showed that both Akt1 and Akt2 inhibited autophagy in MDA-MB-231 cells by downregulating ultraviolet irradiation resistance-associated gene (UVRAG) which is involved in the autophagosome formation and maturation during autophagy (macroautophagy) and sensitized cells to UV irradiation by inhibiting cell proliferation [85]. The effect of Akt1 on UVRAG was independent of Akt1 and mTORC1 activity. Interestingly, while overexpression of Akt1 protected against apoptosis induced by UV irradiation, it decreased cell proliferation by inhibiting autophagy and overcame the anti-apoptotic effect of Akt1. Akt2 also attenuated autophagy by inhibiting the function of the transcription factor EB (TFEB) which regulates the expression of several autophagy-related genes, including LC3B [73]. Phosphorylation of TFEB by mTORC1 causes its cytoplasmic localization and inhibition of its transcriptional activity [109]. The Akt2-specific nanobody Nb8 which was shown to inhibit Akt2 activity and cell cycle progression in MDA-MB-231 cells caused a decrease in TFEB phosphorylation and upregulation of LC3B-II, suggesting Akt2 indirectly regulates TFEB via mTORC1 [73]. Akt3-derived circRNAs hsa_circ_0000199, which has been associated with the clinical pathology of TNBC, was shown to mediate its function by downregulating miR-206 and miR-613 [115]. Silencing of hsa_circ_0000199 decreased cell proliferation, migration and invasion and increased autophagy in TNBC cells and these effects were reversed by inhibitors of miR-206 and miR-613 [115].

Several studies performed in other cell lines suggested additional involvement of Akt isoforms in autophagy. Both Akt1 and Akt2, but not Akt3, were shown to interact with the lysosomal protein pleckstrin homology domain-containing family F member 2 (Phafin2) and knockdown of these isoforms inhibited induction of autophagy. However, only reintroduction of Akt2 but not Akt1 restored autophagy. Interaction of Akt2 with Phafin2 following initiation of autophagy caused accumulation of the complex in the lysosomes where the interaction of Phafin2 with PtdIns(3)P facilitated autophagy induction [116]. The same group showed that vaccinia-related kinase (VRK)-2, a member of the VRK family of serine/threonine protein kinases, also interacts with Akt1 and Akt2 but not Akt 3 and accumulates phosphorylated Akt in the lysosomes [117]. Increase in lysosomal Akt activity was important for lysosomal acidification, activation of lysosomal hydrolases and completion of the autophagy process. The orphan nuclear receptor TR3 or Nur77 was shown to induce autophagy via the mitochondrial signaling pathway [118]. Phosphorylation of TR3 by Akt2 retained it in the nucleus and inhibited autophagic cell death in response to 1-(3,4,5-trihydroxyphenyl)nonan-1-one (THPN) in gastric cancer SGC7901 and cervical cancer Hela cells [119]. Interestingly, while phosphorylation of TR3 at Ser533 inhibited autophagy, phosphorylation of TR3 at Ser351 by Akt1 inhibited apoptosis [119]. Recently, it has been shown that Akt1 and Akt3, but not Akt2, is required for the increase in lysosomal vacuolar $\mathrm{H}^{1}$-ATPase (V-ATPase) activity in response to amino acid starvation [120].

\subsection{Cellular Senescence}

Senescence is defined as prolonged cell cycle arrest and the proteins that inhibit cell cycle progression also play important roles in regulating senescence [121,122]. Since phosphorylation of the tumor suppressor protein $\mathrm{Rb}$ by CDK4/ 6 is required for cell cycle progression, an increase in CDK4/ 6 inhibitor $\mathrm{p} 16 / \mathrm{INK} 4$ which inhibits $\mathrm{Rb}$ phosphorylation can induce senescence by causing cell cycle arrest [123]. On the other hand, the CDK2 inhibitor p21, a transcriptional target of the tumor suppressor protein p53 which halts cell cycle in response to DNA damage or cellular stress, can trigger senescence [124]. While replicative senescence is a normal process of aging, premature senescence could be induced by hyperactivation of oncogenes or cellular stress to suppress tumorigenesis. 
The oncogenic function of Akt could be counteracted by the induction of cellular senescence. Using Akt1/Akt2 double knockout (DKO) mouse embryo fibroblasts it was shown that ablation of Akt1/Akt2 could inhibit replicative senescence as well as premature senescence induced by oxidative stress and Ras oncogene [125]. Activation of Akt induced premature senescence by inhibiting its downstream target FoxO3a transcription factor which scavenges ROS via induction of Sesn3. Chemotherapeutic agents are known to induce premature senescence. Constitutive activation of Akt1 inhibited doxorubicin-induced senescence but appears to augment tamoxifen-induced senescence in breast cancer MCF-7 cells [126]. All three constitutively-active (CA) Akt isoforms were shown to induce senescence in telomerase reverse transcriptase (TERT)-immortalized BJ human fibroblasts (BJ-T) and Akt1 had the most pronounced effect on the induction of senescence [127]. Activated Akt induced senescence by enhancing mTORC1-mediated translation of p53 and increase in its target p21 [127]. Transcriptome and metabolic profiling was utilized to identify the Akt-induced senescence network and the clinical relevance was determined by analyzing TCGA data of fourteen different cancer types, including breast adenocarcinoma [128]. The tumor suppressor protein neurofibromin 1 (NF1) was shown to maintain Akt-induced senescence via suppression of Ras/ERK signaling [128]. In addition, cycle and apoptosis regulator 1 (CCAR1) which is downregulated in breast cancers and FADD which exerts proapoptotic activity in breast cancer were shown to mediate Akt-induced senescence [128]. Overexpression of Akt1 in MDA-MB-231 cells was shown to counteract the effects of the chemokine receptor CXCR2 on breast cancer cell growth, metastasis and chemoresistance by inducing senescence [129].

\subsection{Metabolism}

Altered metabolism is one of the hallmarks of cancer. The most well-known example of metabolic reprogramming in terms of cancer, the Warburg effect, results in increased glucose uptake and elevated lactate production. However, there are other aspects of metabolic regulation that are abnormal in cancer cells. Key enzymes such as succinate dehydrogenase and pyruvate kinase are associated with multiple steps in the tumorigenic process [130]. $p 53$ and $M y c$, which are among the most commonly mutated genes in a variety of cancers, are master regulators of metabolism and through gain of function mutations contribute to cancer progression and metabolic reprogramming [131].

Akt isoforms have been studied for their ability to affect metabolic regulation in cancer cells. Oncogenic Akt activation plays a major role in meeting the metabolic needs of the tumorigenic process. At a broad level, Akt plays a role in metabolic function in breast cancer through the phosphorylation of glycogen synthase kinase 3 (GSK3) at Ser9 [131]. This phosphorylation inhibits GSK3 $\beta$ resulting in a decrease of its kinase activity on its multiple downstream targets like $\beta$-catenin. Upon GSK3 $\beta$ inhibition by Akt, normal effector function of $\beta$-catenin is restored, and $\beta$-catenin can undergo normal nuclear translocation. In breast cancer, overexpression of $\beta$-catenin has been shown to affect lipid metabolism via differential protein expression. Using MCF-7 cells with an endogenous knockdown of $\beta$-catenin Vergara et al. showed alterations in metabolic processes including the tricarboxylic acid cycle (TCA) and lipid metabolism. After $\beta$-catenin knockdown a decrease in expression of acetyl-CoA carboxylase, ATP-citrate lyase, and monoacyl glycerol lipase were all seen, suggesting a significant role in $\beta$-catenin function in breast cancer cells [132].

Altered glucose metabolism is a common hallmark of cancer and it has been shown that constitutively active Akt can promote aerobic glycolysis as well as increase both glycolytic rate and glucose uptake [133,134]. Immunohistochemical analysis of breast cancer specimens by Schmidt et al. showed a correlation between pAkt and glucose transporter 1 (GLUT1) expression in breast cancer specimens, suggesting a role for Akt in the glycolytic phenotype [135]. Knockdown of GLUT4 was shown to induce metabolic reprogramming and decrease viability of breast cancer MCF-7 and MDA-MB-231 cells, and both GLUT1 and GLUT4 have been suggested as prognostic and therapeutic targets in 
breast cancers [136,137]. Akt2 specifically, has been implicated in most studies involving glucose transporters. Beg et al. recently provided evidence that linked Akt2 to both GLUT1 and GLUT4 translocation in adipocytes [138]. Using a method developed by Kajno et al. [139], they showed that Akt2 T309 phosphorylation by PDK1 was responsible for GLUT4 translocation, while both T309 and S474 phosphorylation were required for GLUT1 translocation to the plasma membrane of proliferative cells [138]. These actions of Akt2 can be partly responsible for increased glucose uptake and the reprogramming of metabolism seen in breast cancer.

Akt isoforms have also been implicated in the glycolysis pathway through modulation of regulatory proteins. In MCF-7 cells, Akt1 was shown to interact with hexokinase 2 (HK2), which phosphorylates glucose to glucose-6P [140]. This relationship shows Akt1's involvement in a critical regulatory step that blocks glucose from leaving the cell due to conformational changes from hexokinase phosphorylation resulting in increased glycolysis by breast cancer cells. Phosphofructokinase 1 (PFK1) is another important regulatory enzyme in glycolysis, which catalyzes the ATP-dependent conversion of fructose-6P to fructose-1,6-BP. The platelet form of PFK1 (PFKP) is overexpressed in breast cancer cells and has been associated with increased glycolytic efficiency [141,142]. Lee et al. showed a relationship between Akt1 and PFKP in breast cancer cells. Knockdown/inhibition of Akt1 resulted in a reduced half-life of PFKP, while Myr-Akt1 resulted in prolonged half-life of PFKP [143]. This suggests that Akt1 plays a pro-tumorigenic role via manipulation of PFK1.

Another attribute of breast cancer is alterations in lipid synthesis. Akt has been shown to have multiple effects on tumorigenic lipid synthesis. Little is known about oncogenic Akt isoform specificity in breast cancer in terms of lipid metabolism, but at a homeostatic level Akt1/2/3 have different functions in mammary gland lipid biosynthesis. For example, constitutively-active Akt1 in transgenic mouse mammary glands mediates lipid accumulation during pregnancy, but mostly general Akt studies have made the connection between Akt and lipid metabolism in breast cancer [144]. Akt can directly affect de novo lipid synthesis through interaction with ATP citrate lyase (ACLY). Akt phosphorylates ACLY on S454 resulting in its activation leading to increased production of cytosolic acetyl-CoA which is in turn used in multiple metabolic reactions including sterol and fatty acid synthesis [145]. ACLY is overexpressed in breast cancer and its presence has been suggested as a diagnostic marker for recurrence and possible chemotherapy resistance [146]. While not shown directly in breast cancer yet, Wei et al. showed a link between ACLY and the PI3K-Akt pathway. Utilizing knockdowns of various ovarian cancer cells, they showed that a decrease of ACLY resulted in inhibition of PI3K-Akt possibly through inhibition of p-Akt [147].

Akt also acts on sterol regulatory element-binding protein (SREBP-1/-2) transcription factors and fatty acid synthase (FASN), which are involved in different aspects of fatty acid and sterol synthesis [148]. SREBP transcription factors act on promoter regions of genes responsible for lipogenesis and NADPH production [15]. Bao et al. showed SREBP-1 upregulation in breast cancer and in vitro knockout of SREBP decreased migration and invasion of breast cancer cell lines [149]. Recently Yi et al. demonstrated that in multiple cancer cell lines, including MDA-MB-231, oncogenic activation of Akt protected against ferroptosis via SREBP lipogenesis [150]. FASN is involved in the synthesis of long chain fatty acids and is upregulated in multiple breast cancers [151,152]. Xu et al. were able to show that knockdown of FASN not only affects the metabolic profile of breast cancer lines, but also led to decreases in migration of SK-Br-3 cells [151]. FASN inhibition in MCF-7 and BT-474 cells leads to downregulation of Akt and thus overall breast cancer survival [153]. Akt isoform specificity has yet to be extensively studied in breast cancer in relation to FASN, although prostate cancer studies have revealed a relationship between Akt3 and FASN involving the two as downstream effectors of peroxisome proliferator-activated receptor gamma (PPARG) activation [154]. 
NADPH is a key component of homeostatic lipogenesis and its altered expression is evident in multiple cancers. NADPH has two-fold metabolic functions; fatty acid synthesis involving acetyl-CoA and providing reducing components for multiple cellular processes [155]. Akt has been shown to affect NADPH levels through alteration of the pentose phosphate pathway (PPP), the major source of cytosolic NADPH, through an mTORC1-SREBP axis [156]. Akt has also been shown to affect NADPH production by directly phosphorylating NAD kinase (NADK) and in oncogenic PI3K breast cancer cell line T47D, Akt phosphorylation of NADK facilitated anchorage-independent cell growth [157]. Cui et al. showed that NADPH was involved in apoptosis of breast cancer cells. In multiple breast cancer cell lines, FAS inhibition leading to NADPH accumulation was responsible for apoptosis [158]. These findings together show another mechanism by which oncogenic Akt signaling can contribute to the broad metabolic reprogramming responsible for meeting the needs of developing cancers. NADPH replenishment is a critical step in metabolic functions and understanding the link between Akt and its isoforms and their specific effects on this process could lead to novel therapeutic targets in breast cancer therapy.

\subsection{Tumor Growth, Invasion and Metastasis}

It is well established that PI3K/Akt signaling is frequently deregulated in breast cancer and plays critical roles in tumorigenesis. While Akt contributes to tumor growth by increasing cell proliferation or decreasing cell death, metastatic dissemination of cancer cells from the primary tumor site to a secondary site involves several steps, including epithelial-to-mesenchymal transition (EMT), invasion, intravasation into the blood vessels, anoikis resistance, and extravasation [159]. In this section, we discuss how Akt isoforms regulate tumor growth and various processes leading to metastasis.

Several studies showed that Akt1 and Akt2 have opposite effects on tumor initiation and tumor progression. Arboleda et al. reported that overexpression of active Akt2, but not Akt1 or Akt3, enhanced invasion through collagen IV matrix via upregulation of $\beta 1$-integrin in several breast cancer cells and increased metastasis of MDA-MB-435 xenografts [86] (Table 1). Using a transgenic mouse model, Muller and co-workers demonstrated that mammary-specific expression of activated Akt1 accelerated ErbB2-induced mammary tumorigenesis by enhancing cyclin D1 and cell proliferation but suppressed lung metastases [87], suggesting Akt1 had opposite effects on tumor growth and metastases. Activated Akt2 in the same model system did not affect tumor development but caused a substantial increase in lung metastases [88], supporting the notion that Akt1 and Akt2 have distinct effects on tumor initiation versus tumor progression. A similar conclusion was reached by several different laboratories, although the mechanism by which Akt1 and Akt2 regulated invasion and metastasis differed. When basal-like mammary epithelial MCF-10A cells were stimulated by overexpressing insulin-like growth factor-I receptor (IGF-IR), Akt1 downregulation enhanced EMT and cell migration via activation of ERK whereas Akt2 downregulation suppressed EMT and inhibited migration in 3D cell culture [89]. Palladin, an actin-associated protein, was identified as a specific substrate for Akt1 and not Akt2 and was shown to inhibit Akt1-mediated cell migration in breast cancer cells [90]. Ectopic expression of constitutively-active Akt1 in TNBC cells inhibited invasion and migration by phosphorylating HDM2 which triggered degradation of the transcription factor NFAT [91]. Introduction of constitutively-active Akt1 in HMT-3522 T4-2 breast cancer cells enhanced cell proliferation and survival and promoted tumor growth but inhibited invasion and motility by inducing phosphorylation (T1462) and degradation of TSC2 which regulates cell adhesion and migration via Rho-GTPase [92]. Twist, a transcription factor for EMT [93], was shown to mediate invasion in MCF-7 and MBA-MB-453 cells by transactivating the Akt2 promoter and there was a correlation between Akt2 and Twist expression in late-stage breast cancers [160]. Knockdown of Akt1 increased cell migration and invasion by upregulating $\beta 1$-integrin \& focal adhesion kinase (FAK) whereas Akt2 knockdown inhibited migration and invasion by decreasing F-actin and vimentin in T47D and IBH-6 cells [70]. 
Moreover, based on the analysis of invasive breast cancer samples in TCGA dataset, Akt2, but not Akt1, was associated with worse clinical outcome [70].

A balance between Akt1 and Akt2 decided the invasiveness and metastasis of primary and metastatic breast cancers by differential regulation of miR-200 [94]. Ablation of Akt1, but not Akt2 or Akt3, promoted EMT in MCF-10A cells and increased invasiveness in MMTV-cErb-B2 mice via downregulation of miR-200 which increased Zeb1 and decreased E-cadherin expression. In contrast, Akt2 decreased the abundance of miR-200 in the absence of Akt1, suggesting that the status of both Akt1 and Akt2 is important to determine the ultimate outcome on invasion and metastasis [94]. Li et al. reported that Akt1 knockdown promoted EMT and invasion of breast cancer cells by dephosphorylating and inactivating PIKfyve which caused sustained activation of EGFR and ERK signaling resulting in $\beta$ catenin nuclear accumulation [95]. The activation of cancer-activated fibroblasts (CAF), which facilitates invasion of epithelial cells, required Akt2 which was activated by Snail and was distributed in polarized cells that were more abundant in the area of invasion in human breast tumor tissues [161]. Cancer stem cells (CSC) can lead to tumor initiation and progression as well as metastasis [162]. Knockdown/inhibition of Akt2 inhibited metastatic potential of CSC and non-CSC by inhibiting the expression of TWIST or mTOR and high levels of Akt2 could be detected in circulating tumor cells in orthotopic mouse models [96]. Akt1 E17K mutation in p53 null background inhibited cell migration and invasion in MCF-10A cells by decreasing ZEB1 which caused an increase in E-cadherin and reversal of EMT whereas Akt2 had opposite effect on E-cadherin [97]. While most of the studies have examined the involvement of Akt isoforms in lung metastases, Hinz et al. showed that Akt 3 but not Akt1 or Akt2 activity is elevated in a subline of MDA-MB231 cells that metastasize to bone (MDA-MB-231 BO) and knockdown of Akt3 increased migration, invasion, and bone metastasis via activation of HER2 and discoidin domain receptor (DDR) kinases and downregulation of the TGF $\beta / C T G F$ (connective tissue growth factor) axis [98].

Many molecules/compounds have been shown to induce migration, invasion and metastasis via the Akt2 signaling pathway. WDR26, a WD40 protein that is overexpressed in highly malignant breast cancers and is associated with poor survival of breast cancer patients, selectively bound to Akt2 and not Akt1 [163]. In ER-positive breast cancers, there was a negative correlation between miR-124 and Akt2 expression and overexpression of miR-124 inhibited E2-induced cell proliferation, migration and invasion by downregulating Akt2 [164]. UCH-L1 (ubiquitin C-terminal hydrolase), a deubiquitinase, was shown to specifically interact with and activate Akt2 in MCF-7 breast cancer cells to promote invasion but did not affect cell proliferation [165]. Metformin inhibited cell migration and invasion of several breast cancer cells and metastasis of MDA-MB-231 xenografts by upregulating miR-200c which negatively regulated Akt2 expression [166]. Dietary fatty acids, such as linoleic acid and oleic acid were also shown to promote migration and invasion in breast cancer cells via Akt2 [167,168].

Several molecules also induced invasion and metastasis by inhibiting Akt1. The chemokine receptor CXCR2 promoted breast cancer cell migration, invasion, and metastasis by suppressing Akt1 [129]. The tumor suppresser, 12-O-Tetradecanoyl phorbol-13-acetate (TPA)-inducible sequences 21 (TIS21), an ortholog of B-cell translocation gene 2 (BTG2), inhibited TNBC cell growth and invasion via activation of Akt1 and not Akt2 [169]. A recent study showed that Rho GTPase activating protein 29 (ARHGAP29) interacted with Akt1 and knockdown of ARHGAP29 decreased invasion of breast cancer cells [170]. While ARHGAP29 knockdown downregulated Akt1, the ratio of phosphorylated Akt1 to total Akt1 remained unchanged.

In contrast to most of the published reports that suggest an anti-metastatic function of Akt1, several studies support a pro-metastatic function of Akt1. Ablation of Akt1 in mice not only inhibited ErbB2-induced mammary tumorigenesis and delayed tumor growth by inhibiting phosphorylation of TSC2 at Ser-939, but also decreased lung metastases and reduced migration of mammary epithelial cells both in 2D and 3D cell culture via induction 
and secretion of CXCL16 [99]. Another study reported that knockout of Akt1 in mice inhibited, Akt2 accelerated, and Akt3 had little effect, on the induction of polyoma middle T (PyMT) and ErbB2-driven mammary carcinogenesis [100]. However, while knockout of Akt1 increased invasiveness of ErbB2/Neu-induced tumors, individual knockout of either Akt1 or Akt2 in PyMT mice inhibited metastasis, suggesting a lack of correlation between invasiveness and metastatic potential in this model system [100]. Akt1 induced invasion of immortalized mammary epithelial cells by preventing degradation of matrix metalloprotease (MMP)-2 by the proteasomal pathway [101]. PTEN expression is lost in inflammatory breast cancer (IBC) SUM149 cells [102]. Knockdown of Akt1 inhibited invasion of IBC cells by inhibiting phosphorylation of RhoC GTPase, a substrate for Akt1, but had no effect on non-IBC (nIBC) cells whereas Akt2 knockdown inhibited invasion of nIBC cells but had no effect on the invasiveness of IBC cells [102]. Akt3 knockdown did not affect invasion of either IBC or nIBC cells. On the other hand, Akt1 and Akt2 knockdown had no effect on cell proliferation and apoptosis of IBC cells whereas depletion of Akt3 decreased survival of IBC but not nIBC cells by inducing apoptosis [102]. Akt1 was identified as one of the driver genes frequently mutated in patients with hormone receptorpositive/HER2-negative metastatic breast cancer [171]. Moreover, analysis of patient samples identified Akt1 as a major contributor of metastatic lymph node involvement which is a risk for breast cancer progression [172]. Akt1 was highly expressed in ERpositive recurrent breast cancers and negatively affected overall survival of breast cancer patients [172].

A recent study revealed that cell autonomous versus systemic deletion of Akt1 and Akt2 had a major impact on the function of Akt1 and Akt2 on tumorigenesis and metastasis [103]. Mammary gland-specific cell-autonomous Akt1 deletion inhibited tumor growth but not metastasis. However, systemic deletion of Akt1 but not Akt2 inhibited lung metastasis through impairment of mobilization and survival of tumor-associated neutrophils and neutrophil-specific deletion of Akt1 suppressed metastasis. On the other hand, while systemic or germline Akt2 deletion did not inhibit or enhance tumorigenesis, cell-autonomous Akt2 deletion prevented tumorigenesis by inhibiting ErbB2 expression in the mammary gland. Systemic Akt2 deletion increased circulating insulin levels which caused hyperactivation of Akt1 and possibly Akt3, and maintained ErbB2 expression, thus interfering with the ability of Akt2 deletion to inhibit tumorigenesis at an early stage, but enhanced ErbB2-induced metastasis.

\section{Discussion}

The importance of the Akt signaling pathway in the development and progression of breast cancer cannot be overstated. It is now well recognized that Akt isoforms play distinct roles in various cellular processes. Most early studies were focused on Akt1 and this isoform was associated with most of the oncogenic functions of Akt. It was then realized that Akt1 and Akt2 have opposite roles in breast cancer initiation and progression. Akt1 was shown to promote tumor initiation by enhancing cell proliferation, cell survival and tumor growth, but it inhibited tumor progression [70,89,90,94,95]. In contrast, Akt2 facilitated tumor progression by increasing cell migration, invasion and metastasis $[70,88,89,96,100,160]$. Akt2 was also associated with worse clinical outcome and was considered a worthwhile target for breast cancer therapy [70]. Although Akt3 expression was believed to be restricted to neuronal cells, it is now known that it can also contribute to breast cancer, especially in TNBC $[63,82,84,98,102]$.

A consensus regarding isoform-specific functions of Akt, however, could not be reached even within a particular subtype of breast cancer (Table 1). While knockdown of Akt1 in breast cancer cell lines caused an increase in cell migration and invasion [70,89,90,94,95], genetic ablation of Akt1 in mouse models of mammary tumor decreased tumor metastasis $[99,100]$. However, hyperactivation of Akt1 also led to decrease in metastasis both in vitro and in vivo $[87,88,90-92]$. Likewise, most studies are consistent with the involvement of Akt2 in migration, invasion and metastasis but there are controversies regarding its 
involvement in cell proliferation and tumorigenesis. Akt2 was reported to decrease [100], increase $[71,73,89]$ or have no effect on cell proliferation and tumor growth $[82,88]$. Similarly, there are contrasting reports whether depletion of Akt3 increases migration, invasion, and bone metastasis [98], decreases cell proliferation and tumor growth [63,82,83], or has no effect on tumorigenesis and lung metastasis [100].

Cellular context plays a major role in deciding the function of Akt isoforms. The environment in live animal is much more complex compared to cultured cells. Ectopic expression of Akt isoforms may have altered localization compared to endogenous Akt isoforms. On the other hand, while germline knockout of Akt isoforms results in complete ablation of Akt isoforms, knockdown of Akt by siRNA may reduce but may not completely eliminate the abundance of Akt isoforms. However, complete ablation of Akt isoforms may lead to compensatory increase in other signaling pathways. Moreover, since Akt isoforms can regulate each other, the status of Akt isoforms in a particular cell type may influence their function. It is, however, hard to reconcile why the function of Akt isoforms vary even with the same cell line. For example, while some studies suggested knockdown of Akt2 decreased proliferation of MDA-MB-231 cells [71,73,107], other studies suggested knockdown of Akt1 and Akt3, but not Akt2, decreased MDA-MB-231 cell growth [63,82]. The threshold of Akt activity such as hyperactivation of Akt by certain stimulus (e.g., oxidative stress) or overexpression of CA-Akt may have different consequences compared to physiological activation of Akt isoforms. For example, while activation of Akt promotes tumorigenesis by increasing cell proliferation and survival (Table 1), hyperactivation of Akt by reactive oxygen species could suppress tumorigenesis by inducing cellular senescence [125].

A recent study revealed a completely different picture of how Akt1 and Akt2 contribute to tumor development and metastasis based on systemic versus autonomous deletion of Akt1 and Akt2 [103]. Systemic Akt1 deletion inhibited lung metastases whereas systemic Akt2 deletion enhanced mammary tumorigenesis and metastasis at least in HER2enriched and luminal B mouse models of breast cancer [103]. Moreover, Akt1 was recently identified as one of the driver genes more frequently mutated in hormone receptor-positive metastatic breast cancer [171] and contributed to metastatic lymph node involvement [172].

\section{Conclusions}

In summary, our notion about which Akt isoform to target for cancer therapy is changing. Most studies are consistent with the roles for Akt1 in cell proliferation, cell survival and tumorigenesis and it appears to play a predominant role in hormone receptor-positive breast cancers. Akt 3 has primarily been associated with the survival and progression of TNBC. The function of Akt1 and Akt2 in tumor progression and metastasis is debatable. While systemic deletion of Akt isoforms validated Akt1 as a suitable target for cancer therapy in hormone receptor-positive and HER2-enriched breast cancers, it remains to be seen how systemic deletion of Akt1, Akt2 and Akt3 in different subtypes of breast cancer affects breast cancer development and progression. Thus, while Akt remains an important target for breast cancer therapy, a complete understanding of how Akt isoforms contribute to breast cancer is essential.

Author Contributions: Conceptualization, A.B., writing, review and editing, A.B., writing, C.B.L., supervision, A.B. All authors have read and agreed to the published version of the manuscript.

Funding: This research received no external funding.

Institutional Review Board Statement: Not applicable.

Informed Consent Statement: Not applicable.

Data Availability Statement: Not applicable.

Acknowledgments: We apologize if we inadvertently left out any major contribution in this field. Images were created with BioRender. 
Conflicts of Interest: The authors declare no conflict of interest.

\section{Abbreviations}

\begin{tabular}{|c|c|}
\hline Abbreviation & Definition \\
\hline AL (A-loop) & Activation loop \\
\hline CCAR1 & Cycle and apoptosis regulator 1 \\
\hline CDK & Cyclin-dependent kinase \\
\hline CKI & Cyclin-dependent kinase inhibitor \\
\hline DNA-PK & DNA-dependent protein kinase \\
\hline EGFR & Epidermal growth factor receptor \\
\hline EMT & Epithelial-to-mesenchymal transition \\
\hline ER & Estrogen receptor \\
\hline ErbB2 & Epidermal growth factor receptor 2 \\
\hline ERK & Extracellular signal-regulated kinase \\
\hline FADD & Fas-associated death domain \\
\hline HER2 & Human epidermal growth factor receptor 2 \\
\hline HM & Hydrophobic motif \\
\hline MAP1LC3/LC3 & Microtubule-associated protein 1 light chain 3 \\
\hline MEF & Mouse embryo fibroblasts \\
\hline mTOR & Mechanistic target of rapamycin \\
\hline mTORC1 & Mechanistic target of rapamycin complex 1 \\
\hline mTORC2 & Mechanistic target of rapamycin complex 2 \\
\hline NF1 & Neurofibromin 1 \\
\hline PDK1 & Phosphoinositide-dependent kinase 1 \\
\hline $\mathrm{PH}$ & Pleckstrin homology \\
\hline PHLPP & PH domain and leucine-rich repeat protein phosphatase \\
\hline РI3K & Phosphatidylinositol 3- kinase \\
\hline PIK3CA & PI3K catalytic subunit alpha \\
\hline PIP2 & Phosphatidylinositol $(4,5)$-bisphosphate \\
\hline PIP3 & Phosphatidylinositol $(3,4,5)$-triphosphate \\
\hline PKB & Protein kinase $\mathrm{B}$ \\
\hline PP2A & Protein phosphatase 2A \\
\hline PR & Progesterone receptor \\
\hline PKC & Protein kinase $\mathrm{C}$ \\
\hline PTEN & Phosphatase and tensin homolog deleted on chromosome 10 \\
\hline SETDB1 & SET domain bifurcated 1 \\
\hline Skp2 & S-phase kinase associated protein 2 \\
\hline TCGA & The cancer genome atlas \\
\hline TERT & Telomerase reverse transcriptase \\
\hline TFEB & Transcription factor EB \\
\hline TIM & TOR-interacting motif \\
\hline TM & Turn motif \\
\hline TNBC & Triple-negative breast cancer \\
\hline TRAF6 & Tumor necrosis factor receptor-associated factor 6 \\
\hline UVRAG & Ultraviolet irradiation resistance-associated gene \\
\hline
\end{tabular}

\section{References}

1. $\quad$ Parker, J.S.; Mullins, M.; Cheang, M.C.; Leung, S.; Voduc, D.; Vickery, T.; Davies, S.; Fauron, C.; He, X.; Hu, Z.; et al. Supervised risk predictor of breast cancer based on intrinsic subtypes. J. Clin. Oncol. 2009, 27, 1160-1167. [CrossRef]

2. Inwald, E.C.; Koller, M.; Klinkhammer-Schalke, M.; Zeman, F.; Hofstadter, F.; Gerstenhauer, M.; Brockhoff, G.; Ortmann, O. 4-IHC classification of breast cancer subtypes in a large cohort of a clinical cancer registry: Use in clinical routine for therapeutic decisions and its effect on survival. Breast Cancer Res. Treat. 2015, 153, 647-658. [CrossRef]

3. Pascual, J.; Turner, N.C. Targeting the PI3-kinase pathway in triple-negative breast cancer. Ann. Oncol. 2019, 30, 1051-1060. [CrossRef]

4. Lee, J.J.; Loh, K.; Yap, Y.S. PI3K/Akt/mTOR inhibitors in breast cancer. Cancer Biol. Med. 2015, 12, 342-354. [CrossRef]

5. Vanhaesebroeck, B.; Guillermet-Guibert, J.; Graupera, M.; Bilanges, B. The emerging mechanisms of isoform-specific PI3K signalling. Nat. Rev. Mol. Cell Biol. 2010, 11, 329-341. [CrossRef] 
6. Parsons, R. Discovery of the PTEN Tumor Suppressor and Its Connection to the PI3K and AKT Oncogenes. Cold Spring Harb. Perspect. Med. 2020, 10. [CrossRef]

7. Fusco, N.; Malapelle, U.; Fassan, M.; Marchio, C.; Buglioni, S.; Zupo, S.; Criscitiello, C.; Vigneri, P.; Dei Tos, A.P.; Maiorano, E.; et al. PIK3CA Mutations as a Molecular Target for Hormone Receptor-Positive, HER2-Negative Metastatic Breast Cancer. Front. Oncol. 2021, 11, 644737. [CrossRef] [PubMed]

8. Baselga, J. Targeting the phosphoinositide-3 (PI3) kinase pathway in breast cancer. Oncologist 2011, 16 (Suppl. 1), 12-19. [CrossRef] [PubMed]

9. She, Q.B.; Chandarlapaty, S.; Ye, Q.; Lobo, J.; Haskell, K.M.; Leander, K.R.; DeFeo-Jones, D.; Huber, H.E.; Rosen, N. Breast tumor cells with PI3K mutation or HER2 amplification are selectively addicted to Akt signaling. PLoS ONE 2008, 3, e3065. [CrossRef]

10. Shah, S.P.; Roth, A.; Goya, R.; Oloumi, A.; Ha, G.; Zhao, Y.; Turashvili, G.; Ding, J.; Tse, K.; Haffari, G.; et al. The clonal and mutational evolution spectrum of primary triple-negative breast cancers. Nature 2012, 486, 395-399. [CrossRef] [PubMed]

11. Tsutsui, S.; Inoue, H.; Yasuda, K.; Suzuki, K.; Higashi, H.; Era, S.; Mori, M. Reduced expression of PTEN protein and its prognostic implications in invasive ductal carcinoma of the breast. Oncology 2005, 68, 398-404. [CrossRef] [PubMed]

12. Chan, T.O.; Rittenhouse, S.E.; Tsichlis, P.N. AKT/PKB and other D3 phosphoinositide-regulated kinases: Kinase activation by phosphoinositide-dependent phosphorylation. Annu. Rev. Biochem. 1999, 68, 965-1014. [CrossRef]

13. Coffer, P.J.; Woodgett, J.R. Molecular cloning and characterisation of a novel putative protein-serine kinase related to the cAMP-dependent and protein kinase C families. Eur. J. Biochem. 1991, 201, 475-481. [CrossRef] [PubMed]

14. Pretre, V.; Wicki, A. Inhibition of Akt and other AGC kinases: A target for clinical cancer therapy? Semin. Cancer Biol. 2018, 48, 70-77. [CrossRef] [PubMed]

15. Hoxhaj, G.; Manning, B.D. The PI3K-AKT network at the interface of oncogenic signalling and cancer metabolism. Nat. Rev. Cancer 2020, 20, 74-88. [CrossRef] [PubMed]

16. Yu, J.S.; Cui, W. Proliferation, survival and metabolism: The role of PI3K/AKT/mTOR signalling in pluripotency and cell fate determination. Development 2016, 143, 3050-3060. [CrossRef] [PubMed]

17. Manning, B.D.; Toker, A. AKT/PKB Signaling: Navigating the Network. Cell 2017, 169, 381-405. [CrossRef]

18. Staal, S.P.; Huebner, K.; Croce, C.M.; Parsa, N.Z.; Testa, J.R. The AKT1 proto-oncogene maps to human chromosome 14, band q32. Genomics 1988, 2, 96-98. [CrossRef]

19. Cheng, J.Q.; Godwin, A.K.; Bellacosa, A.; Taguchi, T.; Franke, T.F.; Hamilton, T.C.; Tsichlis, P.N.; Testa, J.R. AKT2, a putative oncogene encoding a member of a subfamily of protein-serine/threonine kinases, is amplified in human ovarian carcinomas. Proc. Natl. Acad. Sci. USA 1992, 89, 9267-9271. [CrossRef]

20. Nakatani, K.; Thompson, D.A.; Barthel, A.; Sakaue, H.; Liu, W.; Weigel, R.J.; Roth, R.A. Up-regulation of Akt3 in estrogen receptor-deficient breast cancers and androgen-independent prostate cancer lines. J. Biol. Chem. 1999, 274, 21528-21532. [CrossRef]

21. Risso, G.; Blaustein, M.; Pozzi, B.; Mammi, P.; Srebrow, A. Akt/PKB: One kinase, many modifications. Biochem. J. 2015, 468, 203-214. [CrossRef]

22. Clark, A.R.; Toker, A. Signalling specificity in the Akt pathway in breast cancer. Biochem. Soc. Trans. 2014, 42, 1349-1355. [CrossRef]

23. Guo, H.; Gao, M.; Lu, Y.; Liang, J.; Lorenzi, P.L.; Bai, S.; Hawke, D.H.; Li, J.; Dogruluk, T.; Scott, K.L.; et al. Coordinate phosphorylation of multiple residues on single AKT1 and AKT2 molecules. Oncogene 2014, 33, 3463-3472. [CrossRef]

24. Lucic, I.; Rathinaswamy, M.K.; Truebestein, L.; Hamelin, D.J.; Burke, J.E.; Leonard, T.A. Conformational sampling of membranes by Akt controls its activation and inactivation. Proc. Natl. Acad. Sci. USA 2018, 115, E3940-E3949. [CrossRef]

25. Mora, A.; Komander, D.; van Aalten, D.M.; Alessi, D.R. PDK1, the master regulator of AGC kinase signal transduction. Semin. Cell Dev. Biol. 2004, 15, 161-170. [CrossRef]

26. Sarbassov, D.D.; Guertin, D.A.; Ali, S.M.; Sabatini, D.M. Phosphorylation and regulation of Akt/PKB by the rictor-mTOR complex. Science 2005, 307, 1098-1101. [CrossRef]

27. Bozulic, L.; Surucu, B.; Hynx, D.; Hemmings, B.A. PKBalpha/Akt1 acts downstream of DNA-PK in the DNA double-strand break response and promotes survival. Mol. Cell 2008, 30, 203-213. [CrossRef]

28. Kim, M.J.; Byun, J.Y.; Yun, C.H.; Park, I.C.; Lee, K.H.; Lee, S.J. c-Src-p38 mitogen-activated protein kinase signaling is required for Akt activation in response to ionizing radiation. Mol. Cancer Res. 2008, 6, 1872-1880. [CrossRef] [PubMed]

29. McDonald, P.C.; Oloumi, A.; Mills, J.; Dobreva, I.; Maidan, M.; Gray, V.; Wederell, E.D.; Bally, M.B.; Foster, L.J.; Dedhar, S. Rictor and integrin-linked kinase interact and regulate Akt phosphorylation and cancer cell survival. Cancer Res. 2008, 68, 1618-1624 [CrossRef] [PubMed]

30. Yang, L.; Qiao, G.; Ying, H.; Zhang, J.; Yin, F. TCR-induced Akt serine 473 phosphorylation is regulated by protein kinase C-alpha. Biochem. Biophys Res. Commun. 2010, 400, 16-20. [CrossRef] [PubMed]

31. Kawakami, Y.; Nishimoto, H.; Kitaura, J.; Maeda-Yamamoto, M.; Kato, R.M.; Littman, D.R.; Leitges, M.; Rawlings, D.J.; Kawakami, T. Protein kinase $C$ betaII regulates Akt phosphorylation on Ser-473 in a cell type- and stimulus-specific fashion. J. Biol. Chem. 2004, 279, 47720-47725. [CrossRef] [PubMed]

32. Halaby, M.J.; Hibma, J.C.; He, J.; Yang, D.Q. ATM protein kinase mediates full activation of Akt and regulates glucose transporter 4 translocation by insulin in muscle cells. Cell. Signal. 2008, 20, 1555-1563. [CrossRef] [PubMed]

33. Xie, X.; Zhang, D.; Zhao, B.; Lu, M.K.; You, M.; Condorelli, G.; Wang, C.Y.; Guan, K.L. IkappaB kinase epsilon and TANK-binding kinase 1 activate AKT by direct phosphorylation. Proc. Natl. Acad. Sci. USA 2011, 108, 6474-6479. [CrossRef] [PubMed] 
34. Dan, H.C.; Antonia, R.J.; Baldwin, A.S. PI3K/Akt promotes feedforward mTORC2 activation through IKKalpha. Oncotarget 2016, 7, 21064-21075. [CrossRef]

35. Chen, K.; Jiao, X.; Di Rocco, A.; Shen, D.; Xu, S.; Ertel, A.; Yu, Z.; Di Sante, G.; Wang, M.; Li, Z.; et al. Endogenous Cyclin D1 Promotes the Rate of Onset and Magnitude of Mitogenic Signaling via Akt1 Ser473 Phosphorylation. Cell Rep. 2020, $32,108151$. [CrossRef] [PubMed]

36. Warfel, N.A.; Niederst, M.; Newton, A.C. Disruption of the interface between the pleckstrin homology (PH) and kinase domains of Akt protein is sufficient for hydrophobic motif site phosphorylation in the absence of mTORC2. J. Biol. Chem. 2011, 286, 39122-39129. [CrossRef]

37. Andjelkovic, M.; Alessi, D.R.; Meier, R.; Fernandez, A.; Lamb, N.J.; Frech, M.; Cron, P.; Cohen, P.; Lucocq, J.M.; Hemmings, B.A. Role of translocation in the activation and function of protein kinase B. J. Biol. Chem. 1997, 272, 31515-31524. [CrossRef]

38. Oh, W.J.; Wu, C.C.; Kim, S.J.; Facchinetti, V.; Julien, L.A.; Finlan, M.; Roux, P.P.; Su, B.; Jacinto, E. mTORC2 can associate with ribosomes to promote cotranslational phosphorylation and stability of nascent Akt polypeptide. EMBO J. 2010, 29, 3939-3951. [CrossRef]

39. Hiraoka, D.; Okumura, E.; Kishimoto, T. Turn motif phosphorylation negatively regulates activation loop phosphorylation in Akt. Oncogene 2011, 30, 4487-4497. [CrossRef]

40. Baffi, T.R.; Lorden, G.; Wozniak, J.M.; Feichtner, A.; Yeung, W.; Kornev, A.P.; King, C.C.; Del Rio, J.C.; Limaye, A.J.; Bogomolovas, J.; et al. mTORC2 controls the activity of PKC and Akt by phosphorylating a conserved TOR interaction motif. Sci. Signal. 2021, 14. [CrossRef]

41. Liu, P.; Begley, M.; Michowski, W.; Inuzuka, H.; Ginzberg, M.; Gao, D.; Tsou, P.; Gan, W.; Papa, A.; Kim, B.M.; et al. Cellcycle-regulated activation of Akt kinase by phosphorylation at its carboxyl terminus. Nature 2014, 508, 541-545. [CrossRef] [PubMed]

42. Chu, N.; Viennet, T.; Bae, H.; Salguero, A.; Boeszoermenyi, A.; Arthanari, H.; Cole, P.A. The structural determinants of PH domain-mediated regulation of Akt revealed by segmental labeling. Elife 2020, 9. [CrossRef] [PubMed]

43. Plotz, G.; Lopez-Garcia, L.A.; Brieger, A.; Zeuzem, S.; Biondi, R.M. Alternative AKT2 splicing produces protein lacking the hydrophobic motif regulatory region. PLOS ONE 2020, 15, e242819. [CrossRef] [PubMed]

44. Maehama, T.; Dixon, J.E. The tumor suppressor, PTEN/MMAC1, dephosphorylates the lipid second messenger, phosphatidylinositol 3,4,5-trisphosphate. J. Biol. Chem. 1998, 273, 13375-13378. [CrossRef]

45. Gewinner, C.; Wang, Z.C.; Richardson, A.; Teruya-Feldstein, J.; Etemadmoghadam, D.; Bowtell, D.; Barretina, J.; Lin, W.M.; Rameh, L.; Salmena, L.; et al. Evidence that inositol polyphosphate 4-phosphatase type II is a tumor suppressor that inhibits PI3K signaling. Cancer Cell 2009, 16, 115-125. [CrossRef] [PubMed]

46. Resjo, S.; Goransson, O.; Harndahl, L.; Zolnierowicz, S.; Manganiello, V.; Degerman, E. Protein phosphatase 2A is the main phosphatase involved in the regulation of protein kinase B in rat adipocytes. Cell. Signal. 2002, 14, 231-238. [CrossRef]

47. Gao, T.; Furnari, F.; Newton, A.C. PHLPP: A phosphatase that directly dephosphorylates Akt, promotes apoptosis, and suppresses tumor growth. Mol. Cell 2005, 18, 13-24. [CrossRef]

48. Brognard, J.; Sierecki, E.; Gao, T.; Newton, A.C. PHLPP and a second isoform, PHLPP2, differentially attenuate the amplitude of Akt signaling by regulating distinct Akt isoforms. Mol. Cell 2007, 25, 917-931. [CrossRef]

49. Wang, G.; Long, J.; Gao, Y.; Zhang, W.; Han, F.; Xu, C.; Sun, L.; Yang, S.C.; Lan, J.; Hou, Z.; et al. SETDB1-mediated methylation of Akt promotes its K63-linked ubiquitination and activation leading to tumorigenesis. Nat. Cell Biol. 2019, 21, 214-225. [CrossRef]

50. Yang, W.L.; Wu, C.Y.; Wu, J.; Lin, H.K. Regulation of Akt signaling activation by ubiquitination. Cell Cycle 2010, 9, 487-497. [CrossRef]

51. Yang, W.L.; Wang, J.; Chan, C.H.; Lee, S.W.; Campos, A.D.; Lamothe, B.; Hur, L.; Grabiner, B.C.; Lin, X.; Darnay, B.G.; et al. The E3 ligase TRAF6 regulates Akt ubiquitination and activation. Science 2009, 325, 1134-1138. [CrossRef] [PubMed]

52. Bae, S.; Kim, S.Y.; Jung, J.H.; Yoon, Y.; Cha, H.J.; Lee, H.; Kim, K.; Kim, J.; An, I.S.; Kim, J.; et al. Akt is negatively regulated by the MULAN E3 ligase. Cell Res. 2012, 22, 873-885. [CrossRef] [PubMed]

53. Carpten, J.D.; Faber, A.L.; Horn, C.; Donoho, G.P.; Briggs, S.L.; Robbins, C.M.; Hostetter, G.; Boguslawski, S.; Moses, T.Y.; Savage, S.; et al. A transforming mutation in the pleckstrin homology domain of AKT1 in cancer. Nature 2007, 448, 439-444. [CrossRef]

54. Mancini, M.L.; Lien, E.C.; Toker, A. Oncogenic AKT1(E17K) mutation induces mammary hyperplasia but prevents HER2-driven tumorigenesis. Oncotarget 2016, 7, 17301-17313. [CrossRef] [PubMed]

55. Rudolph, M.; Anzeneder, T.; Schulz, A.; Beckmann, G.; Byrne, A.T.; Jeffers, M.; Pena, C.; Politz, O.; Kochert, K.; Vonk, R.; et al. AKT1 (E17K) mutation profiling in breast cancer: Prevalence, concurrent oncogenic alterations, and blood-based detection. BMC Cancer 2016, 16, 622. [CrossRef] [PubMed]

56. Lopez-Cortes, A.; Paz, Y.M.C.; Guerrero, S.; Cabrera-Andrade, A.; Barigye, S.J.; Munteanu, C.R.; Gonzalez-Diaz, H.; Pazos, A.; Perez-Castillo, Y.; Tejera, E. OncoOmics approaches to reveal essential genes in breast cancer: A panoramic view from pathogenesis to precision medicine. Sci. Rep. 2020, 10, 5285. [CrossRef]

57. Smyth, L.M.; Zhou, Q.; Nguyen, B.; Yu, C.; Lepisto, E.M.; Arnedos, M.; Hasset, M.J.; Lenoue-Newton, M.L.; Blauvelt, N.; Dogan, S.; et al. Characteristics and Outcome of AKT1 (E17K)-Mutant Breast Cancer Defined through AACR Project GENIE, a Clinicogenomic Registry. Cancer Discov. 2020, 10, 526-535. [CrossRef] [PubMed] 
58. Salhia, B.; Van Cott, C.; Tegeler, T.; Polpitiya, A.; Duquette, R.A.; Gale, M.; Hostteter, G.; Petritis, K.; Carpten, J. Differential effects of AKT1(p.E17K) expression on human mammary luminal epithelial and myoepithelial cells. Hum. Mutat. 2012, 33, $1216-1227$. [CrossRef]

59. Stemke-Hale, K.; Gonzalez-Angulo, A.M.; Lluch, A.; Neve, R.M.; Kuo, W.L.; Davies, M.; Carey, M.; Hu, Z.; Guan, Y.; Sahin, A.; et al. An integrative genomic and proteomic analysis of PIK3CA, PTEN, and AKT mutations in breast cancer. Cancer Res. 2008, 68, 6084-6091. [CrossRef]

60. Stephens, P.J.; Tarpey, P.S.; Davies, H.; Van Loo, P.; Greenman, C.; Wedge, D.C.; Nik-Zainal, S.; Martin, S.; Varela, I.; Bignell, G.R.; et al. The landscape of cancer genes and mutational processes in breast cancer. Nature 2012, 486, 400-404. [CrossRef]

61. van Geelen, C.T.; Savas, P.; Teo, Z.L.; Luen, S.J.; Weng, C.F.; Ko, Y.A.; Kuykhoven, K.S.; Caramia, F.; Salgado, R.; Francis, P.A.; et al. Clinical implications of prospective genomic profiling of metastatic breast cancer patients. Breast Cancer Res. 2020, $22,91$. [CrossRef] [PubMed]

62. Bellacosa, A.; de Feo, D.; Godwin, A.K.; Bell, D.W.; Cheng, J.Q.; Altomare, D.A.; Wan, M.; Dubeau, L.; Scambia, G.; Masciullo, V.; et al. Molecular alterations of the AKT2 oncogene in ovarian and breast carcinomas. Int. J. Cancer 1995, 64, 280-285. [CrossRef] [PubMed]

63. Chin, Y.R.; Yoshida, T.; Marusyk, A.; Beck, A.H.; Polyak, K.; Toker, A. Targeting Akt3 signaling in triple-negative breast cancer. Cancer Res. 2014, 74, 964-973. [CrossRef]

64. Turner, K.M.; Sun, Y.; Ji, P.; Granberg, K.J.; Bernard, B.; Hu, L.; Cogdell, D.E.; Zhou, X.; Yli-Harja, O.; Nykter, M.; et al. Genomically amplified Akt3 activates DNA repair pathway and promotes glioma progression. Proc. Natl. Acad. Sci. USA 2015, 112, 3421-3426. [CrossRef] [PubMed]

65. Banerji, S.; Cibulskis, K.; Rangel-Escareno, C.; Brown, K.K.; Carter, S.L.; Frederick, A.M.; Lawrence, M.S.; Sivachenko, A.Y.; Sougnez, C.; Zou, L.; et al. Sequence analysis of mutations and translocations across breast cancer subtypes. Nature 2012, 486, 405-409. [CrossRef] [PubMed]

66. Wang, D.Y.; Jiang, Z.; Ben-David, Y.; Woodgett, J.R.; Zacksenhaus, E. Molecular stratification within triple-negative breast cancer subtypes. Sci. Rep. 2019, 9, 19107. [CrossRef]

67. Hinz, N.; Jucker, M. Distinct functions of AKT isoforms in breast cancer: A comprehensive review. Cell Commun. Signal. 2019, 17, 154. [CrossRef]

68. Giacinti, C.; Giordano, A. RB and cell cycle progression. Oncogene 2006, 25, 5220-5227. [CrossRef]

69. Abukhdeir, A.M.; Park, B.H. P21 and p27: Roles in carcinogenesis and drug resistance. Expert Rev. Mol. Med. 2008, 10, e19. [CrossRef]

70. Riggio, M.; Perrone, M.C.; Polo, M.L.; Rodriguez, M.J.; May, M.; Abba, M.; Lanari, C.; Novaro, V. AKT1 and AKT2 isoforms play distinct roles during breast cancer progression through the regulation of specific downstream proteins. Sci. Rep. 2017, 7, 44244. [CrossRef]

71. Santi, S.A.; Lee, H. Ablation of Akt2 induces autophagy through cell cycle arrest, the downregulation of p70S6K, and the deregulation of mitochondria in MDA-MB231 cells. PLoS ONE 2011, 6, e14614. [CrossRef] [PubMed]

72. Johnson, J.; Chow, Z.; Napier, D.; Lee, E.; Weiss, H.L.; Evers, B.M.; Rychahou, P. Targeting PI3K and AMPKalpha Signaling Alone or in Combination to Enhance Radiosensitivity of Triple Negative Breast Cancer. Cells 2020, 9, 1253. [CrossRef] [PubMed]

73. Merckaert, T.; Zwaenepoel, O.; Gevaert, K.; Gettemans, J. An AKT2-specific nanobody that targets the hydrophobic motif induces cell cycle arrest, autophagy and loss of focal adhesions in MDA-MB-231 cells. Biomed. Pharmacother. 2021, 133, 111055. [CrossRef] [PubMed]

74. Child, E.S.; Mann, D.J. The intricacies of p21 phosphorylation: Protein/protein interactions, subcellular localization and stability. Cell Cycle 2006, 5, 1313-1319. [CrossRef]

75. Viglietto, G.; Motti, M.L.; Bruni, P.; Melillo, R.M.; D’Alessio, A.; Califano, D.; Vinci, F.; Chiappetta, G.; Tsichlis, P.; Bellacosa, A.; et al. Cytoplasmic relocalization and inhibition of the cyclin-dependent kinase inhibitor p27(Kip1) by PKB/Aktmediated phosphorylation in breast cancer. Nat. Med. 2002, 8, 1136-1144. [CrossRef]

76. Liang, J.; Zubovitz, J.; Petrocelli, T.; Kotchetkov, R.; Connor, M.K.; Han, K.; Lee, J.H.; Ciarallo, S.; Catzavelos, C.; Beniston, R.; et al. PKB/Akt phosphorylates p27, impairs nuclear import of p27 and opposes p27-mediated G1 arrest. Nat. Med. 2002, 8, 1153-1160. [CrossRef]

77. Shin, I.; Yakes, F.M.; Rojo, F.; Shin, N.Y.; Bakin, A.V.; Baselga, J.; Arteaga, C.L. PKB/Akt mediates cell-cycle progression by phosphorylation of p27(Kip1) at threonine 157 and modulation of its cellular localization. Nat. Med. 2002, 8, 1145-1152. [CrossRef]

78. Li, Y.; Dowbenko, D.; Lasky, L.A. AKT/PKB phosphorylation of p21Cip/WAF1 enhances protein stability of p21Cip/WAF1 and promotes cell survival. J. Biol. Chem. 2002, 277, 11352-11361. [CrossRef]

79. Heron-Milhavet, L.; Franckhauser, C.; Rana, V.; Berthenet, C.; Fisher, D.; Hemmings, B.A.; Fernandez, A.; Lamb, N.J. Only Akt1 is required for proliferation, while Akt2 promotes cell cycle exit through p21 binding. Mol. Cell. Biol. 2006, 26, 8267-8280. [CrossRef]

80. Gao, D.; Inuzuka, H.; Tseng, A.; Chin, R.Y.; Toker, A.; Wei, W. Phosphorylation by Akt1 promotes cytoplasmic localization of Skp2 and impairs APCCdh1-mediated Skp2 destruction. Nat. Cell Biol. 2009, 11, 397-408. [CrossRef]

81. Xu, N.; Lao, Y.; Zhang, Y.; Gillespie, D.A. Akt: A double-edged sword in cell proliferation and genome stability. J. Oncol. 2012, 2012, 951724. [CrossRef] 
82. Toulany, M.; Maier, J.; Iida, M.; Rebholz, S.; Holler, M.; Grottke, A.; Juker, M.; Wheeler, D.L.; Rothbauer, U.; Rodemann, H.P. Akt1 and Akt3 but not Akt2 through interaction with DNA-PKcs stimulate proliferation and post-irradiation cell survival of K-RAS-mutated cancer cells. Cell Death Discov. 2017, 3, 17072. [CrossRef] [PubMed]

83. Grabinski, N.; Mollmann, K.; Milde-Langosch, K.; Muller, V.; Schumacher, U.; Brandt, B.; Pantel, K.; Jucker, M. AKT3 regulates ErbB2, ErbB3 and estrogen receptor alpha expression and contributes to endocrine therapy resistance of ErbB2(+) breast tumor cells from Balb-neuT mice. Cell. Signal. 2014, 26, 1021-1029. [CrossRef] [PubMed]

84. Suyama, K.; Yao, J.; Liang, H.; Benard, O.; Loudig, O.D.; Amgalan, D.; McKimpson, W.M.; Phillips, G.R.; Segall, J.; Wang, Y.; et al. An Akt3 Splice Variant Lacking the Serine 472 Phosphorylation Site Promotes Apoptosis and Suppresses Mammary Tumorigenesis. Cancer Res. 2018, 78, 103-114. [CrossRef]

85. Yang, W.; Ju, J.H.; Lee, K.M.; Nam, K.; Oh, S.; Shin, I. Protein kinase B/Akt1 inhibits autophagy by down-regulating UVRAG expression. Exp. Cell Res. 2013, 319, 122-133. [CrossRef]

86. Arboleda, M.J.; Lyons, J.F.; Kabbinavar, F.F.; Bray, M.R.; Snow, B.E.; Ayala, R.; Danino, M.; Karlan, B.Y.; Slamon, D.J. Overexpression of AKT2/protein kinase Bbeta leads to up-regulation of beta1 integrins, increased invasion, and metastasis of human breast and ovarian cancer cells. Cancer Res. 2003, 63, 196-206.

87. Hutchinson, J.N.; Jin, J.; Cardiff, R.D.; Woodgett, J.R.; Muller, W.J. Activation of Akt-1 (PKB-alpha) can accelerate ErbB-2-mediated mammary tumorigenesis but suppresses tumor invasion. Cancer Res. 2004, 64, 3171-3178. [CrossRef]

88. Dillon, R.L.; Marcotte, R.; Hennessy, B.T.; Woodgett, J.R.; Mills, G.B.; Muller, W.J. Akt1 and akt2 play distinct roles in the initiation and metastatic phases of mammary tumor progression. Cancer Res. 2009, 69, 5057-5064. [CrossRef] [PubMed]

89. Irie, H.Y.; Pearline, R.V.; Grueneberg, D.; Hsia, M.; Ravichandran, P.; Kothari, N.; Natesan, S.; Brugge, J.S. Distinct roles of Akt1 and Akt2 in regulating cell migration and epithelial-mesenchymal transition. J. Cell Biol. 2005, 171, 1023-1034. [CrossRef] [PubMed]

90. Chin, Y.R.; Toker, A. The actin-bundling protein palladin is an Akt1-specific substrate that regulates breast cancer cell migration. Mol. Cell 2010, 38, 333-344. [CrossRef] [PubMed]

91. Yoeli-Lerner, M.; Yiu, G.K.; Rabinovitz, I.; Erhardt, P.; Jauliac, S.; Toker, A. Akt blocks breast cancer cell motility and invasion through the transcription factor NFAT. Mol. Cell 2005, 20, 539-550. [CrossRef] [PubMed]

92. Liu, H.; Radisky, D.C.; Nelson, C.M.; Zhang, H.; Fata, J.E.; Roth, R.A.; Bissell, M.J. Mechanism of Akt1 inhibition of breast cancer cell invasion reveals a protumorigenic role for TSC2. Proc. Natl. Acad. Sci. USA 2006, 103, 4134-4139. [CrossRef] [PubMed]

93. Wang, Y.; Liu, J.; Ying, X.; Lin, P.C.; Zhou, B.P. Twist-mediated Epithelial-mesenchymal Transition Promotes Breast Tumor Cell Invasion via Inhibition of Hippo Pathway. Sci. Rep. 2016, 6, 24606. [CrossRef]

94. Iliopoulos, D.; Polytarchou, C.; Hatziapostolou, M.; Kottakis, F.; Maroulakou, I.G.; Struhl, K.; Tsichlis, P.N. MicroRNAs differentially regulated by Akt isoforms control EMT and stem cell renewal in cancer cells. Sci. Signal. 2009, 2, ra62. [CrossRef]

95. Li, W.; Hou, J.Z.; Niu, J.; Xi, Z.Q.; Ma, C.; Sun, H.; Wang, C.J.; Fang, D.; Li, Q.; Xie, S.Q. Akt1 inhibition promotes breast cancer metastasis through EGFR-mediated beta-catenin nuclear accumulation. Cell Commun. Signal. 2018, 16, 82. [CrossRef]

96. Gener, P.; Rafael, D.; Seras-Franzoso, J.; Perez, A.; Pindado, L.A.; Casas, G.; Arango, D.; Fernandez, Y.; Diaz-Riascos, Z.V.; Abasolo, I.; et al. Pivotal Role of AKT2 during Dynamic Phenotypic Change of Breast Cancer Stem Cells. Cancers 2019, 11, 1058. [CrossRef]

97. Gao, S.P.; Kiliti, A.J.; Zhang, K.; Vasani, N.; Mao, N.; Jordan, E.; Wise, H.C.; Shrestha Bhattarai, T.; Hu, W.; Dorso, M.; et al. AKT1 E17K Inhibits Cancer Cell Migration by Abrogating beta-Catenin Signaling. Mol. Cancer. Res. 2021, 19, 573-584. [CrossRef] [PubMed]

98. Hinz, N.; Baranowsky, A.; Horn, M.; Kriegs, M.; Sibbertsen, F.; Smit, D.J.; Clezardin, P.; Lange, T.; Schinke, T.; Jucker, M. Knockdown of AKT3 Activates HER2 and DDR Kinases in Bone-Seeking Breast Cancer Cells, Promotes Metastasis In Vivo and Attenuates the TGFbeta/CTGF Axis. Cells 2021, 10, 430. [CrossRef] [PubMed]

99. Ju, X.; Katiyar, S.; Wang, C.; Liu, M.; Jiao, X.; Li, S.; Zhou, J.; Turner, J.; Lisanti, M.P.; Russell, R.G.; et al. Akt1 governs breast cancer progression in vivo. Proc. Natl. Acad. Sci. USA 2007, 104, 7438-7443. [CrossRef]

100. Maroulakou, I.G.; Oemler, W.; Naber, S.P.; Tsichlis, P.N. Akt1 ablation inhibits, whereas Akt2 ablation accelerates, the development of mammary adenocarcinomas in mouse mammary tumor virus (MMTV)-ErbB2/neu and MMTV-polyoma middle T transgenic mice. Cancer Res. 2007, 67, 167-177. [CrossRef]

101. Park, B.K.; Zeng, X.; Glazer, R.I. Akt1 induces extracellular matrix invasion and matrix metalloproteinase-2 activity in mouse mammary epithelial cells. Cancer Res. 2001, 61, 7647-7653.

102. Lehman, H.L.; Van Laere, S.J.; van Golen, C.M.; Vermeulen, P.B.; Dirix, L.Y.; van Golen, K.L. Regulation of inflammatory breast cancer cell invasion through Akt1/PKBalpha phosphorylation of RhoC GTPase. Mol. Cancer Res. 2012, 10, 1306-1318. [CrossRef]

103. Chen, X.; Ariss, M.M.; Ramakrishnan, G.; Nogueira, V.; Blaha, C.; Putzbach, W.; Islam, A.; Frolov, M.V.; Hay, N. Cell-Autonomous versus Systemic Akt Isoform Deletions Uncovered New Roles for Akt1 and Akt2 in Breast Cancer. Mol. Cell 2020, 80, 87-101.e105. [CrossRef] [PubMed]

104. Héron-Milhavet, L.; Mamaeva, D.; Rochat, A.; Lamb, N.J.C.; Fernandez, A. Akt2 is implicated in skeletal muscle differentiation and specifically binds Prohibitin2/REA. J. Cell. Physiol. 2008, 214, 158-165. [CrossRef] [PubMed]

105. Yang, J.; Li, B.; He, Q.-Y. Significance of prohibitin domain family in tumorigenesis and its implication in cancer diagnosis and treatment. Cell Death Dis. 2018, 9, 580. [CrossRef] [PubMed] 
106. Heron-Milhavet, L.; Franckhauser, C.; Fernandez, A.; Lamb, N.J. Characterization of the Akt2 domain essential for binding nuclear p21cip1 to promote cell cycle arrest during myogenic differentiation. PLoS ONE 2013, 8, e76987. [CrossRef] [PubMed]

107. Bai, Y.; Li, J.; Li, J.; Liu, Y.; Zhang, B. MiR-615 inhibited cell proliferation and cell cycle of human breast cancer cells by suppressing of AKT2 expression. Int. J. Clin. Exp. Med. 2015, 8, 3801-3808. [PubMed]

108. Hu, X.; Wang, J.; He, W.; Zhao, P.; Ye, C. MicroRNA-433 targets AKT3 and inhibits cell proliferation and viability in breast cancer. Oncol. Lett. 2018, 15, 3998-4004. [CrossRef] [PubMed]

109. Dossou, A.S.; Basu, A. The Emerging Roles of mTORC1 in Macromanaging Autophagy. Cancers 2019, 11, 1422. [CrossRef] [PubMed]

110. Zarzynska, J.M. The importance of autophagy regulation in breast cancer development and treatment. Biomed. Res. Int. 2014, 2014, 710345. [CrossRef]

111. Levine, B.; Klionsky, D.J. Development by self-digestion: Molecular mechanisms and biological functions of autophagy. Dev. Cell 2004, 6, 463-477. [CrossRef]

112. Avalos, Y.; Canales, J.; Bravo-Sagua, R.; Criollo, A.; Lavandero, S.; Quest, A.F. Tumor suppression and promotion by autophagy. Biomed. Res. Int. 2014, 2014, 603980. [CrossRef]

113. Maiuri, M.C.; Tasdemir, E.; Criollo, A.; Morselli, E.; Vicencio, J.M.; Carnuccio, R.; Kroemer, G. Control of autophagy by oncogenes and tumor suppressor genes. Cell Death Differ. 2009, 16, 87-93. [CrossRef] [PubMed]

114. Corum, D.G.; Tsichlis, P.N.; Muise-Helmericks, R.C. AKT3 controls mitochondrial biogenesis and autophagy via regulation of the major nuclear export protein CRM-1. FASEB J. 2014, 28, 395-407. [CrossRef]

115. Li, H.; Xu, W.; Xia, Z.; Liu, W.; Pan, G.; Ding, J.; Li, J.; Wang, J.; Xie, X.; Jiang, D. Hsa_circ_0000199 facilitates chemo-tolerance of triple-negative breast cancer by interfering with miR-206/613-led PI3K/Akt/mTOR signaling. Aging (Albany NY) 2021, 13, 4522-4551. [CrossRef]

116. Matsuda-Lennikov, M.; Suizu, F.; Hirata, N.; Hashimoto, M.; Kimura, K.; Nagamine, T.; Fujioka, Y.; Ohba, Y.; Iwanaga, T.; Noguchi, M. Lysosomal interaction of Akt with Phafin2: A critical step in the induction of autophagy. PLoS ONE 2014, 9, e79795. [CrossRef] [PubMed]

117. Hirata, N.; Suizu, F.; Matsuda-Lennikov, M.; Tanaka, T.; Edamura, T.; Ishigaki, S.; Donia, T.; Lithanatudom, P.; Obuse, C.; Iwanaga, T.; et al. Functional characterization of lysosomal interaction of Akt with VRK2. Oncogene 2018, 37, 5367-5386. [CrossRef]

118. Wang, W.J.; Wang, Y.; Chen, H.Z.; Xing, Y.Z.; Li, F.W.; Zhang, Q.; Zhou, B.; Zhang, H.K.; Zhang, J.; Bian, X.L.; et al. Orphan nuclear receptor TR3 acts in autophagic cell death via mitochondrial signaling pathway. Nat. Chem. Biol. 2014, 10, 133-140. [CrossRef]

119. Wang, W.J.; Wang, Y.; Hou, P.P.; Li, F.W.; Zhou, B.; Chen, H.Z.; Bian, X.L.; Cai, Q.X.; Xing, Y.Z.; He, J.P.; et al. Induction of Autophagic Death in Cancer Cells by Agonizing TR3 and Attenuating Akt2 Activity. Chem. Biol. 2015, 22, 1040-1051. [CrossRef]

120. Collins, M.P.; Stransky, L.A.; Forgac, M. AKT Ser/Thr kinase increases V-ATPase-dependent lysosomal acidification in response to amino acid starvation in mammalian cells. J. Biol. Chem. 2020, 295, 9433-9444. [CrossRef]

121. Munoz-Espin, D.; Serrano, M. Cellular senescence: From physiology to pathology. Nat. Rev. Mol. Cell Biol. 2014, 15, 482-496. [CrossRef] [PubMed]

122. Basu, A. The interplay between apoptosis and cellular senescence: Bcl-2 family proteins as targets for cancer therapy. Pharmacol. Ther. 2021. [CrossRef] [PubMed]

123. Ohtani, N.; Yamakoshi, K.; Takahashi, A.; Hara, E. The p16INK4a-RB pathway: Molecular link between cellular senescence and tumor suppression. J. Med. Investig. 2004, 51, 146-153. [CrossRef] [PubMed]

124. Mijit, M.; Caracciolo, V.; Melillo, A.; Amicarelli, F.; Giordano, A. Role of p53 in the Regulation of Cellular Senescence. Biomolecules 2020, 10, 420. [CrossRef]

125. Nogueira, V.; Park, Y.; Chen, C.C.; Xu, P.Z.; Chen, M.L.; Tonic, I.; Unterman, T.; Hay, N. Akt determines replicative senescence and oxidative or oncogenic premature senescence and sensitizes cells to oxidative apoptosis. Cancer Cell 2008, 14, 458-470. [CrossRef]

126. Taylor, J.R.; Lehmann, B.D.; Chappell, W.H.; Abrams, S.L.; Steelman, L.S.; McCubrey, J.A. Cooperative effects of Akt-1 and Raf-1 on the induction of cellular senescence in doxorubicin or tamoxifen treated breast cancer cells. Oncotarget 2011, 2, 610-626. [CrossRef]

127. Astle, M.V.; Hannan, K.M.; Ng, P.Y.; Lee, R.S.; George, A.J.; Hsu, A.K.; Haupt, Y.; Hannan, R.D.; Pearson, R.B. AKT induces senescence in human cells via mTORC1 and p53 in the absence of DNA damage: Implications for targeting mTOR during malignancy. Oncogene 2012, 31, 1949-1962. [CrossRef]

128. Chan, K.T.; Blake, S.; Zhu, H.; Kang, J.; Trigos, A.S.; Madhamshettiwar, P.B.; Diesch, J.; Paavolainen, L.; Horvath, P.; Hannan, R.D.; et al. A functional genetic screen defines the AKT-induced senescence signaling network. Cell Death Differ. 2020, 27, 725-741. [CrossRef]

129. Xu, H.; Lin, F.; Wang, Z.; Yang, L.; Meng, J.; Ou, Z.; Shao, Z.; Di, G.; Yang, G. CXCR2 promotes breast cancer metastasis and chemoresistance via suppression of AKT1 and activation of COX2. Cancer Lett. 2018, 412, 69-80. [CrossRef]

130. Dalla Pozza, E.; Dando, I.; Pacchiana, R.; Liboi, E.; Scupoli, M.T.; Donadelli, M.; Palmieri, M. Regulation of succinate dehydrogenase and role of succinate in cancer. Semin. Cell Dev. Biol. 2020, 98, 4-14. [CrossRef]

131. Liu, J.; Zhang, C.; Hu, W.; Feng, Z. Tumor suppressor p53 and metabolism. J. Mol. Cell Biol. 2019, 11, 284-292. [CrossRef]

132. Vergara, D.; Stanca, E.; Guerra, F.; Priore, P.; Gaballo, A.; Franck, J.; Simeone, P.; Trerotola, M.; De Domenico, S.; Fournier, I.; et al. beta-Catenin Knockdown Affects Mitochondrial Biogenesis and Lipid Metabolism in Breast Cancer Cells. Front. Physiol. 2017, 8, 544. [CrossRef] 
133. Buzzai, M.; Bauer, D.E.; Jones, R.G.; Deberardinis, R.J.; Hatzivassiliou, G.; Elstrom, R.L.; Thompson, C.B. The glucose dependence of Akt-transformed cells can be reversed by pharmacologic activation of fatty acid beta-oxidation. Oncogene 2005, 24, $4165-4173$. [CrossRef]

134. Elstrom, R.L.; Bauer, D.E.; Buzzai, M.; Karnauskas, R.; Harris, M.H.; Plas, D.R.; Zhuang, H.; Cinalli, R.M.; Alavi, A.; Rudin, C.M.; et al. Akt stimulates aerobic glycolysis in cancer cells. Cancer Res. 2004, 64, 3892-3899. [CrossRef] [PubMed]

135. Schmidt, M.; Voelker, H.U.; Kapp, M.; Krockenberger, M.; Dietl, J.; Kammerer, U. Glycolytic phenotype in breast cancer: Activation of Akt, up-regulation of GLUT1, TKTL1 and down-regulation of M2PK. J. Cancer. Res. Clin. Oncol. 2010, 136, 219-225. [CrossRef] [PubMed]

136. Barbosa, A.M.; Martel, F. Targeting Glucose Transporters for Breast Cancer Therapy: The Effect of Natural and Synthetic Compounds. Cancers 2020, 12, 154. [CrossRef]

137. Garrido, P.; Osorio, F.G.; Moran, J.; Cabello, E.; Alonso, A.; Freije, J.M.; Gonzalez, C. Loss of GLUT4 induces metabolic reprogramming and impairs viability of breast cancer cells. J. Cell. Physiol. 2015, 230, 191-198. [CrossRef]

138. Beg, M.; Abdullah, N.; Thowfeik, F.S.; Altorki, N.K.; McGraw, T.E. Distinct Akt phosphorylation states are required for insulin regulated Glut4 and Glut1-mediated glucose uptake. Elife 2017, 6. [CrossRef] [PubMed]

139. Kajno, E.; McGraw, T.E.; Gonzalez, E. Development of a new model system to dissect isoform specific Akt signalling in adipocytes. Biochem. J. 2015, 468, 425-434. [CrossRef] [PubMed]

140. Yang, T.; Ren, C.; Qiao, P.; Han, X.; Wang, L.; Lv, S.; Sun, Y.; Liu, Z.; Du, Y.; Yu, Z. PIM2-mediated phosphorylation of hexokinase 2 is critical for tumor growth and paclitaxel resistance in breast cancer. Oncogene 2018, 37, 5997-6009. [CrossRef]

141. Wang, G.; Xu, Z.; Wang, C.; Yao, F.; Li, J.; Chen, C.; Sun, S. Differential phosphofructokinase-1 isoenzyme patterns associated with glycolytic efficiency in human breast cancer and paracancer tissues. Oncol. Lett. 2013, 6, 1701-1706. [CrossRef]

142. Moon, J.S.; Kim, H.E.; Koh, E.; Park, S.H.; Jin, W.J.; Park, B.W.; Park, S.W.; Kim, K.S. Kruppel-like factor 4 (KLF4) activates the transcription of the gene for the platelet isoform of phosphofructokinase (PFKP) in breast cancer. J. Biol. Chem. 2011, 286, 23808-23816. [CrossRef]

143. Lee, J.H.; Liu, R.; Li, J.; Zhang, C.; Wang, Y.; Cai, Q.; Qian, X.; Xia, Y.; Zheng, Y.; Piao, Y.; et al. Stabilization of phosphofructokinase 1 platelet isoform by AKT promotes tumorigenesis. Nat. Commun. 2017, 8, 949. [CrossRef] [PubMed]

144. Schwertfeger, K.L.; McManaman, J.L.; Palmer, C.A.; Neville, M.C.; Anderson, S.M. Expression of constitutively activated Akt in the mammary gland leads to excess lipid synthesis during pregnancy and lactation. J. Lipid Res. 2003, 44, 1100-1112. [CrossRef] [PubMed]

145. Berwick, D.C.; Hers, I.; Heesom, K.J.; Moule, S.K.; Tavare, J.M. The identification of ATP-citrate lyase as a protein kinase B (Akt) substrate in primary adipocytes. J. Biol. Chem. 2002, 277, 33895-33900. [CrossRef] [PubMed]

146. Chen, Y.; Li, K.; Gong, D.; Zhang, J.; Li, Q.; Zhao, G.; Lin, P. ACLY: A biomarker of recurrence in breast cancer. Pathol. Res. Pract. 2020, 216, 153076. [CrossRef]

147. Wei, X.; Shi, J.; Lin, Q.; Ma, X.; Pang, Y.; Mao, H.; Li, R.; Lu, W.; Wang, Y.; Liu, P. Targeting ACLY Attenuates Tumor Growth and Acquired Cisplatin Resistance in Ovarian Cancer by Inhibiting the PI3K-AKT Pathway and Activating the AMPK-ROS Pathway. Front. Oncol. 2021, 11, 642229. [CrossRef]

148. Porstmann, T.; Griffiths, B.; Chung, Y.L.; Delpuech, O.; Griffiths, J.R.; Downward, J.; Schulze, A. PKB/Akt induces transcription of enzymes involved in cholesterol and fatty acid biosynthesis via activation of SREBP. Oncogene 2005, 24, 6465-6481. [CrossRef]

149. Bao, J.; Zhu, L.; Zhu, Q.; Su, J.; Liu, M.; Huang, W. SREBP-1 is an independent prognostic marker and promotes invasion and migration in breast cancer. Oncol. Lett. 2016, 12, 2409-2416. [CrossRef]

150. Yi, J.; Zhu, J.; Wu, J.; Thompson, C.B.; Jiang, X. Oncogenic activation of PI3K-AKT-mTOR signaling suppresses ferroptosis via SREBP-mediated lipogenesis. Proc. Natl. Acad. Sci. USA 2020, 117, 31189-31197. [CrossRef]

151. Xu, S.; Chen, T.; Dong, L.; Li, T.; Xue, H.; Gao, B.; Ding, X.; Wang, H.; Li, H. Fatty acid synthase promotes breast cancer metastasis by mediating changes in fatty acid metabolism. Oncol. Lett. 2021, 21, 27. [CrossRef]

152. Cheng, C.S.; Wang, Z.; Chen, J. Targeting FASN in Breast Cancer and the Discovery of Promising Inhibitors from Natural Products Derived from Traditional Chinese Medicine. Evid. Based Complement. Alternat. Med. 2014, 2014, 232946. [CrossRef] [PubMed]

153. Menendez, J.A.; Lupu, R. Fatty acid synthase regulates estrogen receptor-alpha signaling in breast cancer cells. Oncogenesis 2017, 6, e299. [CrossRef]

154. Galbraith, L.C.A.; Mui, E.; Nixon, C.; Hedley, A.; Strachan, D.; MacKay, G.; Sumpton, D.; Sansom, O.J.; Leung, H.Y.; Ahmad, I. PPAR-gamma induced AKT3 expression increases levels of mitochondrial biogenesis driving prostate cancer. Oncogene 2021, 40, 2355-2366. [CrossRef]

155. Jin, E.S.; Lee, M.H.; Murphy, R.E.; Malloy, C.R. Pentose phosphate pathway activity parallels lipogenesis but not antioxidant processes in rat liver. Am. J. Physiol. Endocrinol. Metab. 2018, 314, E543-E551. [CrossRef] [PubMed]

156. Duvel, K.; Yecies, J.L.; Menon, S.; Raman, P.; Lipovsky, A.I.; Souza, A.L.; Triantafellow, E.; Ma, Q.; Gorski, R.; Cleaver, S.; et al. Activation of a metabolic gene regulatory network downstream of mTOR complex 1. Mol. Cell 2010, 39, 171-183. [CrossRef] [PubMed]

157. Hoxhaj, G.; Ben-Sahra, I.; Lockwood, S.E.; Timson, R.C.; Byles, V.; Henning, G.T.; Gao, P.; Selfors, L.M.; Asara, J.M.; Manning, B.D. Direct stimulation of NADP(+) synthesis through Akt-mediated phosphorylation of NAD kinase. Science 2019, 363, 1088-1092. [CrossRef] 
158. Cui, Y.; Xing, P.; Wang, Y.; Liu, M.; Qiu, L.; Ying, G.; Li, B. NADPH accumulation is responsible for apoptosis in breast cancer cells induced by fatty acid synthase inhibition. Oncotarget 2017, 8, 32576-32585. [CrossRef]

159. Geiger, T.R.; Peeper, D.S. Metastasis mechanisms. Biochim. Biophys. Acta 2009, 1796, 293-308. [CrossRef]

160. Cheng, G.Z.; Chan, J.; Wang, Q.; Zhang, W.; Sun, C.D.; Wang, L.H. Twist transcriptionally up-regulates AKT2 in breast cancer cells leading to increased migration, invasion, and resistance to paclitaxel. Cancer Res. 2007, 67, 1979-1987. [CrossRef]

161. Mestre-Farrera, A.; Bruch-Oms, M.; Pena, R.; Rodriguez-Morato, J.; Alba-Castellon, L.; Comerma, L.; Quintela-Fandino, M.; Dunach, M.; Baulida, J.; Pozo, O.J.; et al. Glutamine-Directed Migration of Cancer-Activated Fibroblasts Facilitates Epithelial Tumor Invasion. Cancer Res. 2021, 81, 438-451. [CrossRef]

162. Raman, D.; Tiwari, A.K.; Tiriveedhi, V.; Rhoades Sterling, J.A. Editorial: The Role of Breast Cancer Stem Cells in Clinical Outcomes. Front. Oncol. 2020, 10, 299. [CrossRef]

163. Ye, Y.; Tang, X.; Sun, Z.; Chen, S. Upregulated WDR26 serves as a scaffold to coordinate PI3K/ AKT pathway-driven breast cancer cell growth, migration, and invasion. Oncotarget 2016, 7, 17854-17869. [CrossRef]

164. Jiang, C.F.; Li, D.M.; Shi, Z.M.; Wang, L.; Liu, M.M.; Ge, X.; Liu, X.; Qian, Y.C.; Wen, Y.Y.; Zhen, L.L.; et al. Estrogen regulates miRNA expression: Implication of estrogen receptor and miR-124/AKT2 in tumor growth and angiogenesis. Oncotarget 2016, 7, 36940-36955. [CrossRef] [PubMed]

165. Luo, Y.; He, J.; Yang, C.; Orange, M.; Ren, X.; Blair, N.; Tan, T.; Yang, J.M.; Zhu, H. UCH-L1 promotes invasion of breast cancer cells through activating Akt signaling pathway. J. Cell. Biochem. 2018, 119, 691-700. [CrossRef]

166. Zhang, J.; Li, G.; Chen, Y.; Fang, L.; Guan, C.; Bai, F.; Ma, M.; Lyu, J.; Meng, Q.H. Metformin Inhibits Tumorigenesis and Tumor Growth of Breast Cancer Cells by Upregulating miR-200c but Downregulating AKT2 Expression. J. Cancer 2017, 8, 1849-1864. [CrossRef] [PubMed]

167. Ramirez-Ricardo, J.; Leal-Orta, E.; Garcia-Hernandez, A.; Diaz-Aragon, R.; Cortes-Reynosa, P.; Thompson-Bonilla, R.; Salazar, E.P. Role of Src/FAK in migration and invasion mediated by extracellular vesicles from MDA-MB-231 cells stimulated with linoleic acid. Med. Oncol. 2021, 38, 40. [CrossRef] [PubMed]

168. Marcial-Medina, C.; Ordonez-Moreno, A.; Gonzalez-Reyes, C.; Cortes-Reynosa, P.; Perez Salazar, E. Oleic acid induces migration through a FFAR1/4, EGFR and AKT-dependent pathway in breast cancer cells. Endocr. Connect. 2019, 8, 252-265. [CrossRef] [PubMed]

169. Sundaramoorthy, S.; Devanand, P.; Ryu, M.S.; Song, K.Y.; Noh, D.Y.; Lim, I.K. TIS21(/BTG2) inhibits breast cancer growth and progression by differential regulation of mTORc1 and mTORc2-AKT1-NFAT1-PHLPP2 signaling axis. J. Cancer Res. Clin. Oncol. 2018, 144, 1445-1462. [CrossRef]

170. Kolb, K.; Hellinger, J.; Kansy, M.; Wegwitz, F.; Bauerschmitz, G.; Emons, G.; Grundker, C. Influence of ARHGAP29 on the Invasion of Mesenchymal-Transformed Breast Cancer Cells. Cells 2020, 9, 2616. [CrossRef]

171. Bertucci, F.; Ng, C.K.Y.; Patsouris, A.; Droin, N.; Piscuoglio, S.; Carbuccia, N.; Soria, J.C.; Dien, A.T.; Adnani, Y.; Kamal, M.; et al. Genomic characterization of metastatic breast cancers. Nature 2019, 569, 560-564. [CrossRef] [PubMed]

172. Bonin, S.; Pracella, D.; Barbazza, R.; Dotti, I.; Boffo, S.; Stanta, G. PI3K/AKT Signaling in Breast Cancer Molecular Subtyping and Lymph Node Involvement. Dis. Markers 2019, 2019, 7832376. [CrossRef] [PubMed] 